\author{
Микола Ніколаєв \\ доктор історичних наук, \\ професор кафедри документознавства \\ Університет Григорія Сковороди в \\ Переяславі \\ (Переяслав, Україна)
}

\author{
Mykola Nikolaev \\ Doctor of Historical Sciences \\ (Dr. Hab. in History), Professor of the \\ Department of Documentation \\ The Gregory Skovoroda University in \\ Pereyaslav \\ (Pereyaslav, Ukraine)
}

olbiopol@gmail.com

ORCID: https://orcid.org/0000-0003-3994-1150

ResearcherID: AAH-7628-2020

\title{
ХРОНОЛОГІЯ ОЛЬВІЙСЬКИХ «БОРИСФЕНІВ»
}

\section{THE CHRONOLOGY OF OLBIAN 'BORYSTHENES'}

\section{Анотація.}

Мета статmі - перша (оцінна) спроба побудови хронологічної схеми карбування «борисфенів» усіх груп (та подолання альтернативи між двома найбільш поширеними хронологічними схемами П. О. Каришковського та В. О. Анохіна) иляхом виконання просопографічної інтерпретачії диферентів. Методика дослідження - типові наукові методи у поєднанні з власними науковими розробленнями автора із синхронізації епонімного каталогу IPE I 201 (календаря) та просопографії Ольвї. Наукова новизна. У першому наближенні досліджено історичний контекст, який містять диференти на «борисфенах», тобто виконано ототожнення деяких із них з реальними історичними особами. Відповідно, на иій основі побудована орієнтовна хронологічна модель карбування «борисфенів». Висновки. Диференти на «борисфенах» не мають епонімного характеру, однак приблизно 50-60 \% із них позначають осіб - монетних магістратів, які згідно з античною традицією в суміжні роки обіймали епонімну посаду (це характерно і для емісій «Деметра-орел, дельфін» 360-330 рр. до н. е. тощзо). Диференти (монограми, скорочення), як і імена, підпорядковані стійкій в античному суспільстві традищії родового наслідування. Зазвичай, диференти зазнавали спрощзення не тільки упродовж року, але і в разі застосування їх особами з наступних поколінь, пов'язаних родинними узами (наприклад, $\Sigma \Omega K P \rightarrow \Sigma \Omega K \rightarrow \Sigma \Omega$ та $\Theta E O \rightarrow \Theta E$ або $A \Theta H \rightarrow A \Theta$, або

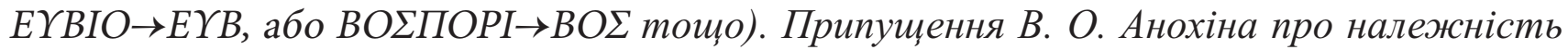
диферентів із різних груп, щзо повторюються, до однієї особи, яка неодноразово брала участь у карбуванні, та, відповідно, про тривалість випуску «борисфенів» не більше двох-трьох десятиліть, суперечить античній традиціі. Початок емісії «борисфенів»330 р. до н. е., завершення - орієнтовно 219 р. до н. е. Перша група «борисфенів» датується з 330 до 319 рр. до н. е. включно, друга - з 307 до 301 рр. до н. е. включно; третя - у діапазоні $290-271^{+12}$ р. до н. е.; четверта-шоста (37 рокових випусків) орієнтовно з $270^{+12}$ до $234^{+12}$ рр. до н. е. включно ${ }^{1}$. Також отримані орієнтовні датування сьомої-десятої груп у діапазоні $232^{+12}-219$ рр. до н. е. Патроніми великої групи епонімів 220 - 208 рр. до н. е. корелюють із диферентами «борисфенів» другої половини випусків n'ятої групи ${ }^{2}$, підтверджуючи, згідно з законом генеалогії, їхнє датування в діапазоні

\footnotetext{
' Нами планується продовження досліджень з метою уточнення хронології III, IV-VI та VII-X груп.

${ }^{2}$ Наприклад, батько епоніма 217 р. до н. е. на ім’я Ми̃ Вобторіхоv залишив диферент ВО $\Sigma$ близько 250-240 рр. до н. е. тощо.
} 
250 - 240 рр. до н. е. За палеографією диферент № 92 не може бути датований раніше останньої третини III cm. до н. е.

B. О. Анохін установив масовий характер зв'язку двох $і$ більше диферентів спільними лицьовими штемпелями, на підставі чого головним висновком дослідника стало припущення про існування спеціальних колегій магістратів, які для I-VI групи налічували шість осіб, а для останніх груп - двох осіб, відповідно, тривалість випуску «борисфенів» складала не більше двох-трьох десятиліть. Схема В. О. Анохіна має протиріччя: збільшення об 'єму емісії останніх груп майэсе у шість разів щцодо перших супроводжувалося зменшенням кількості магістратів - із шести до двох. Застосування ж спільних штемпелів упродовж кількох років (не більше чотирьох) нами пояснюється не однорічною емісією групи магістратів, а реалізацією відомої в античній монетній справі технології, яка передбачала використання кількох однотипних лицьових штемпелів, розташованих поряд на ковадлі. Поява такої технології цілком зрозуміла $з$ огляду на тривалість та інтенсивність випуску. Нам невідомі принципи, якими керувалися монетарії у разі використання того чи іншого лицьового штемпеля, але, ймовірно, така технологія забезпечувала умовно рівномірне їх зношування; своїм наслідком вона мала появу монет із різними комбінаціями диферентів, пов'язаними спільними лицьовими штемпелями, упродовж кількох років.

Отже, із двох найбільш відомих хронологічних схем карбування «борисфенів» (П. О. Каришковського та В. О. Анохіна) ми однозначно віддаємо перевагу схемі П. О. Каришковського (з деякими уточненнями хронологї останніх груп).

Просопографічне дослідження диферентів на «борисфенах» усіх груп виконано вперше, тому його треба сприймати як очінне та наближене. Цілком очевидна необхідність подальших досліджень з метою подолання альтернативних варіантів інтерпретаціï, уточнення та вдосконалення моделі у хронологічній лакуні епонімного каталогу. Також необхідна ревізія інтерпретації скарбів, вивчення нових варіантів диферентів, співвідношення «борисфенів» з іншими монетами, подальше дослідження особливостей родового наслідування монограм та співставлення результатів нумізматичних досліджень із просопографічними.

Ключові слова: Ольвія, «борисфени», монети, монограми, скорочення, ономастика, просопографія, хронологія, історичний контекст.

\section{Summary.}

The aim of the study is a presentation of the chronological model of minting of a 'Borysthenes' of all groups by means of a prosopographic interpretation of their monograms. Research methodology - typical scientific methods in combination with the author's own scientific work by synchronization of the eponyms catalogue IPE I 201 (calendar) and Olbia's prosopography: prosopographic reconstruction, prosopographic dating, prosopographic interpretation. The essence of the proposed tools lies in the study on the chronological basis of the eponyms IPE I 201 catalogue of an extremely narrow stratum of real historical figuresmostly from the hight elite - who traditionally performed alternate senior government positions. Information about the activity of elite contained in various, almost synchronous epigraphic monuments, in this case, an eponyms catalogue, lapidary inscriptions, magical lists, graffiti, agoranomos stamps and weights, coin monograms and abbreviations. Scientific novelty. For the first time, the historical context for the monograms of a 'Borysthenes', that is, the identification with real historical figures have been obtained. Accordingly, a chronological model of minting of a 'Borysthenes' was constructed on this basis. Conclusions. The 
monograms (and/or reductions) of 'Borysthenes' did not have of eponyms character. However, approximately 50-60\% of them correlate with the eponymous catalogue and indicate personsmonetary magistrates, who according to the ancient tradition in adjacent years held an eponymous position. Similarity of monograms from different groups of 'Borysthenes' is a realization of the ancient tradition of generic imitation of names. Accordingly, the similarity monograms (reductions) belong related persons from other generations.

The first group of a 'Borysthenes'dates from 330 to 319 BC. The prosopographic dating of this group is exactly the same as the date of P. O. Karyshkovsky. Of the thirteen coin magistrates who produced a 'Borysthenes' of the first group, seven or eight also was an eponyms incumbency in 337 (?), 330, 329, 327, 326, 325, 324, 320, 319 BC. The second group dates from 307 to $301 \mathrm{BC}$. A real historical fact-four of the seven monograms of the second group of a 'Borysthenes' are concentrated in the narrow chronological section of the eponyms catalogue for 306, 305, 304, 303 BC. The other three monograms are not identified by eponyms. The hypothesis of P. O. Karyshkovsky about the break between the minting of groups I and II is confirmed. This break was about fifteen years. Also, it is possible to narrow down to the end of IV century BC. dating of the second group of a 'Borysthenes', which P. O. Karyshkovsky attributed to the end of IV-beginning of III century. BC. The main problem of our further study is the presence of a chronological lacuna in the eponyms catalogue Olbia IPE I2 201 in the range of 290-227 BC. Prosopographic studies in the lacuna may be available through special tools, but they certainly tend to be more hypothetical and lower in chronological accuracy. The implementation of such studies is based on the preserved fragments of the catalogue of eponyms (both in the lower and the upper part), the possibility of reconstruction of fragments of major genera (according to the law of genealogy), the properties of the theoretical model of the urban community (in particular, the inheritance of coin monograms, the eponyms quotas, etc.), the use of prosopographic information from of relatively accurately dated lapidary inscriptions, agoranomos stamps and weights, also finding of correlation with legends of other coins. The historical figures mentioned in these monuments probably performed the functions of eponyms, magistrates and other. An important auxiliary research tool in the lacuna of catalogue is the relative order of the arrangement of the monograms proposed by P. O. Karyshkovsky.

Unfortunately, the third group of a 'Borysthenes' has an inaccurate prosopographic dating - terminus post quem - 290 BC, terminus ante quem-271 BC. It is a problem our chronological model. The fourth and sixth groups of a 'Borysthenes' (37-year issues) dating from $270^{+12}$ to $234^{+12}$ BC. A patronymics of the large group of eponyms 220-208 BC correlate with the monograms of 'Borysthenes' of the second half of the issues of the fifth group. It confirming, according to the law of genealogy, their dating in the range of 250-240 BC. e. Also, this provides a fairly reliable chronological benchmark in the dating of 'Borysthenes'. The reader can not fail to notice that the obtained prosopographical date of a 'Borysthenes'groups from the first to the sixth inclusive practically corresponds to the materials of P. O. Karyshkovsky. According to our working preliminary hypothesis, the seventh group dates from $232^{+12}$ to $231 \mathrm{BC}$, the eighth to the tenth from $228^{+12}$ to $219 \mathrm{BC}$.

When studying the treasure 1978, V. Anokhin established the mass character of the used of two or more monograms with common front stamps. The main conclusion of the researcher was the assumption of the existence of special boards of magistrates, which for groups I-VI numbered six people, and for the latter groups - two. Accordingly, the duration of the release of 'Borysthenes' was not more than two or three decades. In our opinion, the reason for the mass character of the used of two or more monograms with common front stamps should be sought not in organizational forms, but in the application of technology known in ancient coinage. She involved the use of two or three (or even more) identical face stamps located side 
by side on the anvil. This technology, due to the random nature of use, among other things, provided a relatively uniform wear of several front stamps. As a result, we have the 'Borysthenes' with two or more monograms with common front stamps.

Onomastic research is characterized by the multivariate interpretation of monograms without historical context. However, our prosopographic research also faces the existence of two and sometimes three variants of interpretation of monograms. But unlike onomastics, these variants have a historical component. The task is only to overcome the alternative. We have not yet succeeded in overcoming the alternative in interpreting some of the monograms. Prosopographic study of monograms on a 'Borysthenes' of all groups done for the first time, so it should be seen as estimated and approximate.

Given the complexity of the task, it is obvious that further research is needed to overcome alternative interpretations, refinements, and to obtain new arguments (in particular, joint consideration with agoranomos stamps and weights) regarding the proposed hypotheses. New variants of monograms on a 'Borysthenes' it is necessary to consider, also peculiarities of generic inheritance of monograms, and correlation of a 'Borysthenes' with other coins, as well as comparing the results of numismatic researches with prosopographic ones, etc.

Key words: Olbia, coins, "borysphens", monograms, abbreviations, onomastic, prosopography, chronology, historical context.

Останнім часом дослідники встановили, що найбільш поширені на території сучасної України античні монети - ольвійські «борисфени», - окрім Нижнього Подніпров'я та Нижнього Подністров'я також трапляються й на Середній Наддніпрянщині і навіть у Центральній Свропі ${ }^{1}$. 3 огляду на ареал та величезну кількість «борисфенів», дослідження цих монет, безперечно, - складова проблема античной нумізматики загалом. Проте поряд з успіхами у багаторічному дослідженні «борисфенів» залишається суттева розбіжність у їхньому датуванні, про щзо свідчить аналіз останніх досліджень та публікацій. Так, В. О. Анохін ${ }^{2}$ вважав, що «борисфени» належать близько до 310-280 pр. до н. е., а О. Н. Зограф початок їхнього карбування відносив до другого десятиліття III ст. до н. е., а його завершення - до 20 рр. III ст. до н. е. У свою чергу П. О. Каришковський ${ }^{4}$ датував «борисфени» близько до 330-230 (235) рр. до н. е.,

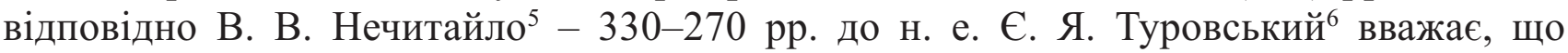
карбування «борисфенів» розпочалося близько середини IV ст. до н. е., а закінчилося дещо раніше 275 р. до н. е. За V. F. Stolba ${ }^{7}$ карбування «борисфенів» відбувалося у 330/325-275 pр. до н. е. Н. О. Фролова та М. Г. Абрамзон указують ${ }^{8}$, що, на думку спеціалістів, «борисфени» карбувалися 3 кінця IV ст. до н. е. до 220 рр. до н. е. До того ж, якщо звернутися до історіографії, яку читач знайде в перелічених вище працях, фактично, датування «борисфенів» виявляється значно ширшим.

\footnotetext{
Mielczarek, M \& Orlyk, V. New find of Olbian coins. Tarashcha district, Kyiv region, Ukraine. Східноєвропейський історичний вісник. 2019. № 13. Р. 33-39; Орлик В., Коцур В., Цыганенко Л. Клад ольвийских монет «борисфенов», найденный в Городищенском районе Черкасской области весной 2018 года. Acta Archaeologica Lodziensia nr 65. 2020. С. 37-48. Нещодавно V. F. Stolba запропонував гіпотезу про застосування «борисфенів» у зерноторгівлі зі скіфами (переважно водним шляхом), що, як варіант, пояснює ареал і кількість цих монет. Див.: Stolbа, V. F. Images with Meaning: Early Hellenistic Coin Typology of Olbia Pontike. Advances in Ancient Black Sea Studies: Historiography, Archaeology and Religion. Editors: V. Cojocaru, L. Ruscu, T. Castelli and A-I. Pázsint. Cluj-Napoca. 2019. P. 530-531. Anokhin C. 58

Зограф А. Н. Античные монеты. М. 1951. С. 131.

${ }^{4}$ Karyshkovskij C. 82.

${ }^{5}$ Nechitailo C. 37.

${ }^{6}$ Туровский Е. Я. Актуальные вопросы нумизматики Ольвии (IV-III вв. до н.э.). Проблемы истории, филологии, культуры. №1. 2015. С. 421430 .

${ }^{7}$ Stolba, V. F. Images with Meaning: Early Hellenistic Coin Typology of Olbia Pontike... P. 525.

${ }^{8}$ Фролова Н. А., Абрамзон М. Г. Монеты Ольвии в собрании Государственного исторического музея: каталог. М. 2005. С. 31.
} 
Треба зауважити, що наші попередники керувалися переважно традиційними, суто нумізматичними методами хронологічних досліджень «борисфенів», наприклад, аналізом штемпелів тощо. Зокрема у дослідженні диферентів використовувалася ономастика, тобто зовсім не враховувався історичний контекст ${ }^{1}$. Ономастичні дослідження диферентів, а втім й епіграфічних пам'яток взагалі, відрізняються багатоваріантністю та не передбачають врахування історичного контексту. Ономастична розвідка диферентів на «борисфенах» представлена у виконаній майже півстоліття тому докторській дисертації видатного вітчизняного вченого П. О. Каришковського 2.

Між тим завдяки синхронізації епонімного каталогу IPE I² 201 (календаря Ольвії) та, відповідно, розбудови основ просопографії останнім часом до наукового обігу запроваджено низку нових інструментів ${ }^{3}$ дослідження різноманітних епіграфічних пам'яток: просопографічна реконструкція, просопографічна інтерпретація та просопографічне датування. Сутність пропонованих інструментів полягає в дослідженні на хронологічному грунті епонімного каталогу IPE $\mathrm{I}^{2} 201$ виключно вузького прошарку реальних історичних осіб - переважно вихідців із вищзої полісної еліти, - які традиційно почергово обіймали державні посади 4 . Впливова історична особа залимає інформацію щзодо своєї діяльності у різноманітних, майже синхронних епіграфічних пам'ятках, $у$ тому числі епонімному каталозі, лапідарних написах 5 , магічних переліках, графіті, агораномних гирях та клеймах, монетних монограмах та скороченнях (диферентах).

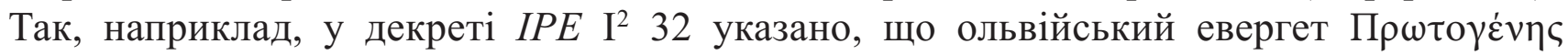

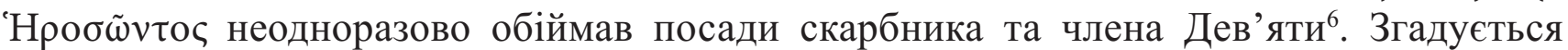
Протоген, ймовірно й у хронологічній лакуні каталогу IPE $\mathrm{I}^{2} 201$, як епонім, оскільки троє його предків та один нащадок обіймали цю посаду. Також не менше двох предків Протогена були монетними магістратами. Послідовне виконання Протогеном посадових обов’язків агоранома та голови колегії агораномів підтверджується двома агораномними

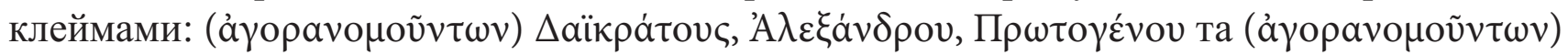

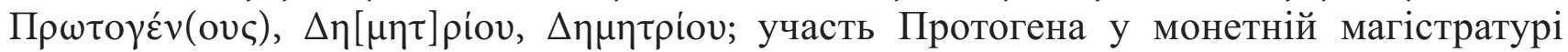
фіксується монетними легендами: ПР $\Omega$, ПР $\Omega \mathrm{THP}^{7}$. Отже, така просопографічна та хронологічна інформація складає підгрунтя для уточнення датування монет та отримання історичного контексту у вигляді ідентифікації особи монетного магістрата. Відновлений календар IPE I² 201 та основи просопографії Ольвї і складають теоретико-методичну основу нашого дослідження. Останніми роками нами вже була обгрунтована можливість

\footnotetext{
Утім, й інших монограмах та скороченнях ольвійських монет, за кількома винятками. Див.: Ніколаєв М. І. Ономастика та просопографія у відновленні монетних монограм (на прикладі Ольвії). Український нумізматичний щорічник. 2019. Вип. 3. С. 8-9.

Подальше читання статті передбачає знайомство з указаним дослідженням. Див.: Карышковский П. О. Монетное дело и денежное обращение Ольвии. Одеса. 2003. § 16.

3 Николаев Н. И. Просопография Ольвии Понтийской V в. до н. э. - І в. н. э. К. 2014. Загалом, обгрунтуванню нових просопографічних інструментів дослідження нами присвячено дві монографії, докторську дисертацію та майже 50 статей. Відповідно, ми очікували кваліфіковані критичні зауваження опонентів. На жаль, опубліковані на сьогодні критичні зауваження - ие викладена в менторському та/або образливому тоні ревізія з погляду традииійної ономастики 80-90 рр. минулого століття отриманих автором просопографічних здобутків. При иьому, за замовчуванням, ономастика абсолютно не спроможна пояснити отриманий просопографічний результат, оскільки зовсім не передбачає врахування історичного контексту! Ось у чому полягає причина висловлених в образливій формі зауважень відомого російського епіграфіста В. П. Яйленка стосовно нашої просопографічної реконструкції фрагментованого напису $S E G$ 58:766. Взагалі, ці зауваження не мають ніякого сенсу з огляду на реальне підтвердження нашої реконструкції шляхом об'єднання фрагменту $S E G 58: 766$ зі знайденим у 1947 р. фрагментом IOlb 125. Див.: Николаев Н. И. Просопографическая реконструкция сокращенных и фрагментированных имен исторических лиц (на примере Ольвии). Емінак: наук. щоквартальник. 2019. № 1 (25). С. 149-157.

${ }^{4}$ Карышковский П. О. Ольвийские эпонимы. Вестник древней истории. 1978. № 2. С. 87-88; Рубан В. В. Магістратура агораномів в Ольвії. Археологія. 1982. № 39. С. 39; Ставнюк В. В. Становлення афінського поліса. Київ. 2005. С. 8, 346; Николаев Н. И. Просопография Ольвии Понтийской V в. до н.э. - І в. н.э. К. 2014.

Майже 90 \% лапідарного архіву догетської Ольвії пов'язано з вищою елітою, до складу якої входило сім родів. Кожному роду притаманні характерні родові імена, епонімні квоти, спеціалізація, пантеон гентільних божеств тощо. Див.: Николаев Н. И. Просопография Ольвии... К. 2014.

${ }^{6}$ Раніше ми вже вказували на датування В. О. Анохіним декрету IPE $\mathrm{I}^{2} 32$ на честь Протогена як на таке, що не відповідає сучасним уявленням, також на його помилкову думку про те, що в цьому декреті не згадуються «борисфени» (див.: Анохин В. А. «Борисфены» и их место... С. 2629; Монеты... С. 34). Див.: Николаев Н. И. Просопография Ольвии Понтийской... С. 197.

Николаев Н. И. Агораномы эллинистической Ольвии. Причерноморье в античное и раннесредневековое время. Вып. 2. Сборник научных трудов, посвященный 70-летию профессора В. П. Копылова. Ростов-на-Дону. 2018. С. 392-406.
} 
просопографічних досліджень монетних монограм та скорочень ${ }^{1}$, підсумком яких стало поетапне уточнення хронології монетних емісій, переважно другої половини IV ст. до н. е., та встановлення участі тієї чи іншої історичної особи у карбуванні, тобто, набуття історичного контексту; також епізодично виконувалися дослідження «борисфенів» першої, другої та останньої груп ${ }^{2}$. Отже, мета статті полягає у першій (оцінній) спробі побудови хронологічної моделі карбування «борисфенів» усіх груп через просопографічну інтерпретацію їхніх диферентів, зокрема у хронологічній лакуні каталогу (290-227 р. до н. е.). Іншими словами, мета статті полягає в подоланні альтернативи між двома найбільш поширеними хронологічними схемами карбування «борисфенів» - П. О. Каришковського та В. О. Анохіна.

Результати наших просопографічних (хронологічних) досліджень оформлені у вигляді більш чи менш ймовірної гіпотези за кожним диферентом ${ }^{3}$ (утім, деяка частина диферентів зовсім не піддається просопографічній інтерпретації). Для зручності розгляд «борисфенів» виконується згідно 3 класифікацією П. О. Каришковського ${ }^{4}$, також застосовано малюнки П. О. Каришковського.

Група I (Karyshkovskij C. 81. № 1-14).

E E E (Karyshkovskij C. 81. №o1,2). Нами вже неодноразово публікувалися5 просопографічні дослідження диферентів №№ 1, 2. На відміну від ономастичного тлумачення ім'я Екат⿱亠䒑 $\omega v^{6}$, присутність на золотих, срібних, свинцевих («облогових») монетах та першому випускові «борисфенів» спільного диференту Е було пояснено його

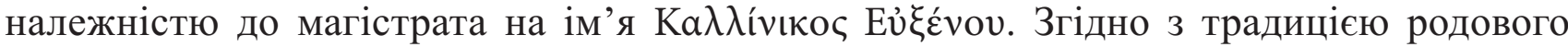

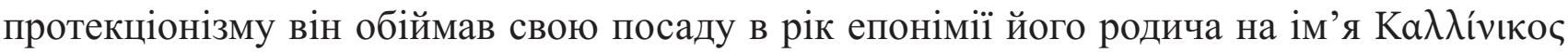
Фı $\lambda$ o $\dot{v} v o v-329^{+2}$ р. до н. е. Таке тлумачення диференту підтверджує інтерпретацію П. О. Каришковським та Ю. Г. Виноградовим декрету IPE $\mathrm{I}^{2} 25+31$ на честь Каллініка Свксенова подіями облоги Ольвії. Крім того, останнім часом до науковий обігу введено новий, очевидно, пробний варіант диференту ⿷ на першому випуску «борисфенів», що підтверджує вірність інтерпретації монограм №№ 1, 2 ім’ям Каллініка Свксенова7 . Датування просопографічне

ф (Karyshkovskij C. 81. № 3). Просопографічна інтерпретація можлива ім’ям Фı $\lambda \tau \tilde{\eta} \varsigma$ $\Lambda \varepsilon \omega v i \delta$ ov. Він - епонім 337 р. до н. е. Втім, підвищує ризик інтерпретації хронологічна відстань приблизно у 8-10 років між епонімією та посадою магістрата. Датування можливе за порядком розташування: близько 329 р. до н. е.

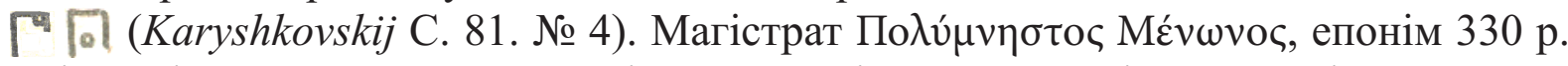
до н. е. Рід невідомий. Альтернативна інтерпретація монограми ім'ям епоніма 332 р. до

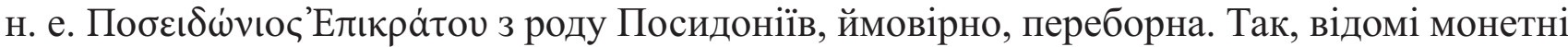
скорочення ПО $\Sigma \mathrm{EI}, \Pi \mathrm{O} \Sigma \mathrm{E}$, що належать представнику Посидоніїв. Досліджувана монограма не відповідає такому скороченню. Існує новий варіант монограми, у якому омікрон зображено у вигляді напівкола. Гіпотезу про те, що диферент № $66 \epsilon$ родовим наслідуванням диференту № 4, слід вважати прийнятною. Датування за порядком розташування: близько 328 р. до н. е. Не виключене й ім'я Поликсен.

\footnotetext{
Ніколаєв М. І. Ономастика та просопографія у відновленні монетних монограм (на прикладі Ольвії IV ст. до н. е.). Український нумізматичний щорічник. 2019. С. 8.

Николаев Н. И. Просопография Ольвии... С. 159-164; 218-222.

Аналогічно з розділом «§ 16. Ономастические данные монетных легенд IV-II вв. до н.э.» докторської дисертації П. О. Каришковського. Див.: Карышковский П. О. Монетное дело... § 16.

${ }^{4}$ Karyshkovskij C. 81.

5 Зокрема, див.: Николаев Н. И. Просопография Ольвии... С. 159-164.

${ }^{6}$ Карышковский П. О. Монетное дело... § 16.

Ніколаєв М. І. Ольвія і Зопіріон: нове історичне джерело. Тези Міжнародного фахового семінару «Проблеми і перспективи античної нумізматики на теренах Південно-Східної Свропи» (У друці).

Наші подальші датування виконані на основі просопографії та/або за порядком розташування диферентів у групі.
} 


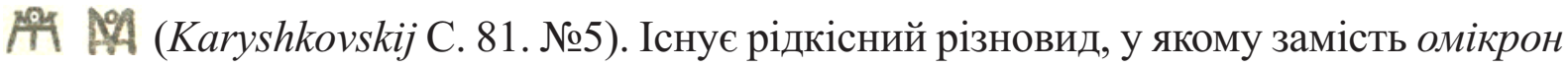
зображена тета. Пропонуємо дуже обережну гіпотезу про належність диференту

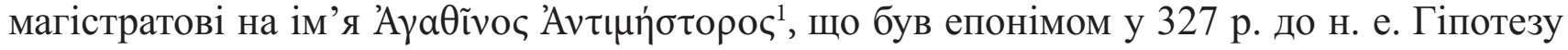
про те, що диференти №№ 70-73 становлять родове наслідування диференту №5, треба вважати прийнятною з огляду на закон генеалогії. Датування за порядком розташування: близько 327 р. до н. е.

D B (Karyshkovskij C. 81. № 6). Зв’язку з епонімами каталогу IPE I² 201 не виявлено. 3 огляду на існування свинцевого «борисфену» ${ }^{2}$ зі спрощеним варіантом диференту зауважимо, що раніше ми пов'язували його інтерпретацію з ім'ям Вро́такоৎ 3 невідомого роду, що зафіксовано в синхронному магічному переліку ${ }^{3}$. Останнім часом, 3 урахуванням практики зображення омикрон у вигляді напівкола (див. диференти № 4 i, ймовірно, №№ 28, 29), пропонуємо більш надійний гіпотетичний варіант інтерпретації: спрощене скорочення ВО або В імені $\mathrm{BO} \Sigma \Pi \mathrm{OPI}(\mathrm{XO} \Sigma)$, що виявлене на синхронному оболі ${ }^{4}$. Датування за порядком розташування: близько 326 р. до н. е.

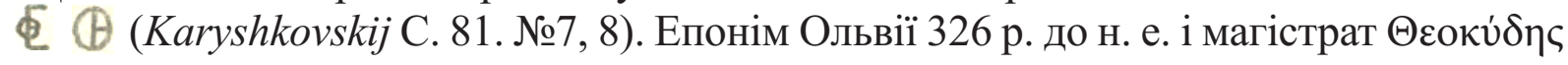
Паүкра́тov 3 невідомого другорядного роду. Відзначається поступове спрощення графічного зображення монограми ${ }^{5}$. Датування монет із розглянутими монограмами, що його запропонував П. О. Каришковський: 330-320 рр. до н. е. Датування просопографічне майже збігається з датуванням за порядком розташування: близько 325 р. до н. е.

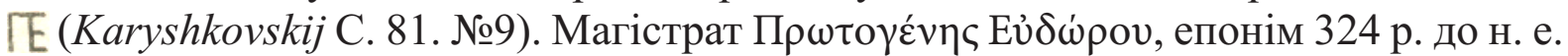
3 елітного роду Протогенів. В. Ф. Столба ${ }^{6}$ опублікував аналогічну монограму на монеті «Тихе (Деметра) - стрілець». Такі монети, на нашу думку, синхронні з «борисфенами» 3 диферентом № 9. Просопографічне датування та датування за порядком розташування майже збігаються: близько 324 р. до н. е.

乏. (Nechitailo № 259; Anokhin № 307). Ймовірно, магістрат Гікесій Сократів (Іке́бıь

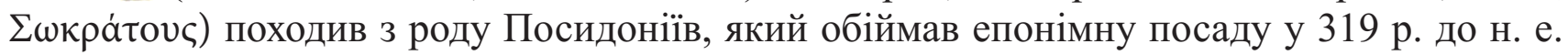
Датування на основі порядку розташування - близько 323 р. до н. е. (Ми використовуємо інформацію В.В. Нечитайла про порядок розташування цього дифферента у групі, однак нам не відомо, з якими диферентами він має спільний лицьовий штемпель. 3 іншого боку, розташування цього «борисфена» останнім у групі I (за В. О. Анохіним) дає практичне співпадання року виконання епонімії та порядку розташування у групі.

I (Karyshkovskij C. 81. №10). Магістрат не обіймав епонімну посаду. Найбільш

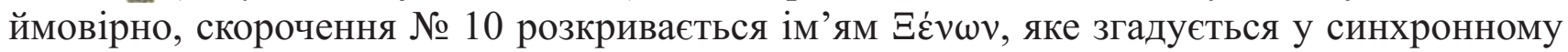
магічному переліку IGDOlb 103. Датування за порядком розташування: близько 322 р. до H. e.

A (Karyshkovskij C. 81. № 11). Просопографічній інтерпретації не піддається; ймовірно, магістрат не виконував епонімну посаду. Датування за порядком розташування: близько 321 р. до н. е.

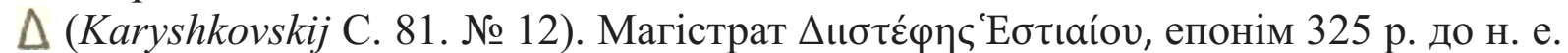
3 невідомого другорядного роду. На синхроних випусках інших монет відомий варіант

\footnotetext{
Основою для гіпотетичної інтерпретації цього досить складного диференту стала просопографічна інформація з синхронізованого епонімного каталогу а також малюнок цього диферента за В.А. Анохіним (див. Anokhin № 298).

Див.: https://www.academia.edu/25981633

${ }^{3}$ Belousov A., Dana M., Nikolaev N. Deux nouvelles defixionum tabellae du territoire d'Olbia du Pont. Zeitschrift für Papyrologie und Epigraphik. 2016. Bd. 197. S. 167-177.

${ }^{4}$ Столба В. Ф. Новые разновидности монет Херсонеса и Ольвии периода автономии // «ПриРОNТийский меняла: деньги местного рынка». VII Международный Нумизматический Симпозиум (Судак, 21-25.09. 2020 г.). Материалы научной конференции / отв. ред. Н. А. Алексеенко. Симферополь: Колорит, 2020. С. 208-209.

5 Поступове спрощення монограм, приналежних однієї особі, було виявлено раніше В. О. Анохіним та П. Й. Каришковським. Див.: Анохин В. А. «Борисфены» и их место... С. 22; Karyshkovskij : 82 .

${ }^{6}$ Stolba V. 'Archers' of the Blessed City: City’s Deliverance in the Coinage of Early Hellenistic Olbia. Notae Numizmaticae. 2015. Vol. 10. C. 43-63.
} 
монограми, який одночасно утримує ім'я та патронім цього магістрата ${ }^{1}$. Просопографічне датування близьке до датування за порядком розташування: близько 320 р. до н. е.

ㅈ 7 (Karyshkovskij C. 81. №№ 13, 14). Епонім 320 р. до н. е. та магістрат

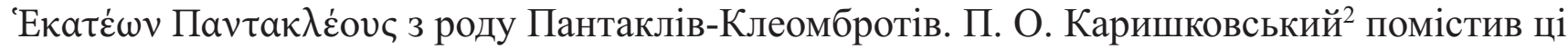
монети між 330-320 рр. до н. е. Водночас В. О. Анохін ${ }^{3}$, датуючи тетрадрахму 3 відповідною монограмою 320-315 рр. до н. е., такуж монограму на «борисфені» першого випуску бездоказово відносить до 310-290 рр. до н. е. У монограмах №13 та №14 спостерігається характерне поступове спрощення графічного зображення впродовж року. Схожі диференти №№ 75-77, очевидно, є прикладом родового наслідування. Датування просопографічне та датування за порядком розташування майже збігаються: близько 319 р. до н. е.

Отже, перша група «борисфенів» хронологічно «тяжіє» до 330-319 рр. до н. е. Просопографічне датування цієї групи на основі синхронізації епонімного каталогу абсолютно збігається з датуванням П. О. Каришковського. 3 тринадцяти магістратів, які випускали «борисфени» першої групи, сім чи навіть вісім також, згідно 3 античною традицією, у суміжні роки обіймали епонімну посаду у 337 (?), 330, 329, 327, 326, 325, 324, 320, 319 рр. до н. е4. Тобто, диференти на «борисфенах»- не епонімна дата.

Немає жодних підстав вважати першу групу, за В. О. Анохіним ${ }^{5}$, одно- або дворічною емісією. Так, спільний лицьовий штемпель до диферентів $\mathbb{E}$ та $\phi-$ перехідний від магістрата Каллініка Євксенова до іншого магістрата, вірогідно, Філта Леонідова. Відповідно, штемпель для групи диферентів $\phi$ та П - перехідний від магістрата,

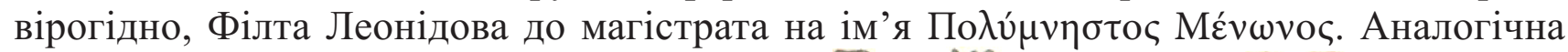

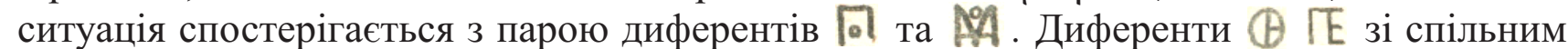
лицьовим штемпелем інтерпретуються як послідовне виконання магістратської посади Феокідом Панкратовим та Протогеном Свдоровим, що були епонімами в 326 та 324 p. до н. е. А ось завершальний випуск першої групи епоніма 320 р. до н. е. та магістрата Гекатеона Пантаклова становлять однорічну емісію $飞 \underset{K}{\nVdash}$ зі спільними лицьовими штемпелями, що зазнають послідовного спрощення.

Група II (Karyshkovskij C. 81. №15-21). Сучасні дослідники, на жаль, залишають поза увагою гіпотезу П. О. Каришковського про перерву в карбуванні між I і II групами; водночас він датує другу групу кінцем IV - початком III ст. до н. е зауваження В. О. Анохіна ${ }^{7}$ про ізольоване положення першої групи, яка не дала перехідних лицьових штемпелів у другу групу. Зіставляючи диференти другої групи 3 епонімним каталогом, отримуємо такі результати:

৫ (Karyshkovskij C. 81. №15). Інтерпретації не піддається. Ймовірно, цей магістрат не обіймав епонімну посаду. Датування за порядком розташування: близько 307 р. до н. е.

N (Karyshkovskij C. 81. №16) Магістрат - епонім 304 р. до н. е. та стінобудівник із

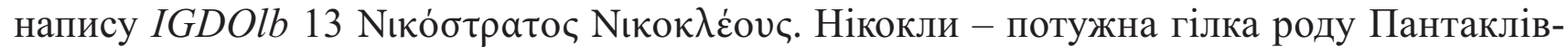
Клеомбротів ${ }^{8}$. Датування просопографічне та датування за порядком розташування майже збігаються: близько 306 р. до н. е.

训 (Karyshkovskij C. 81. №17). Як дуже обережний та попередній варіант

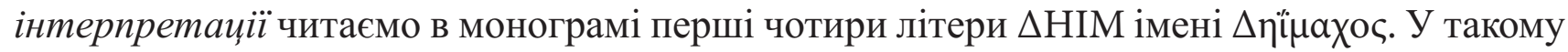
випадку в монограмі згадується ім'я $\Delta \eta^{\prime \prime \mu \alpha \chi о \varsigma ~ ' О \rho \theta о ß о u ́ \lambda o v, ~ щ о ~ б у в ~ е п о н і м о м ~ О л ь в і і ̈ ~}$

${ }^{1}$ Ніколаєв М. І. Ономастика та просопографія у відновленні монетних монограм... С. 20.

2 Карышковский П. О. Ольвийские «борисфены». Нумизматика и сфрагистика. 1968. Вып. 3. С. 74

3 Anokhin №№ 304, 305 та № 287.

4 Безсумнівно, «борисфени» пермої групи мали якийсь особовий статус порівняно з іншими групами. Про це свідчить як склад скарбів, так і відсутність на них клейм «дельфін-зірка».

Анохин В. А. «Борисфены» и их место в монетной системе Ольвии. Античная культура Северного Причерноморья. Киев, 1984. С. 23.

${ }^{6}$ Karyshkovskij C. 82.

Анохин В. А. «Борисфены» и их место... С. 23

${ }^{8}$ Николаев Н. И. Просопография Ольвии... С. 276. 
у 307 р. до н. е. Датування просопографічне та датування за порядком розташування майже збігаються: близько 305 р. до н. е.

Х (Karyshkovskij C. 81. №18). Інтерпретації не піддається. Ймовірно, магістрат не обіймав епонімну посаду. Датування за порядком розташування: близько 304 р. до н. е.

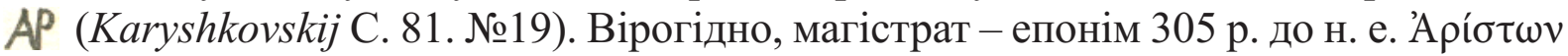

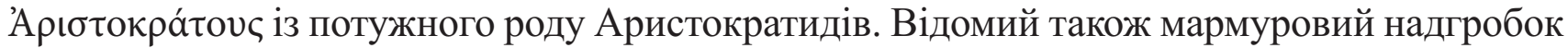

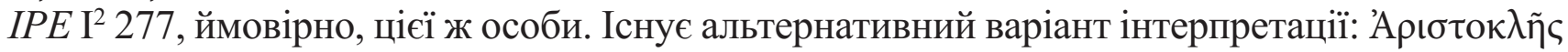

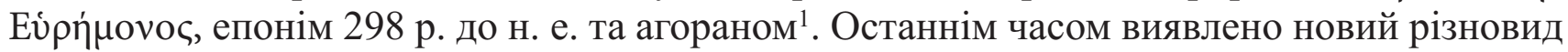
диференту, що потребує дослідження. Датування просопографічне та датування за порядком розташування майже збігаються: близько 303 р. до н. е.

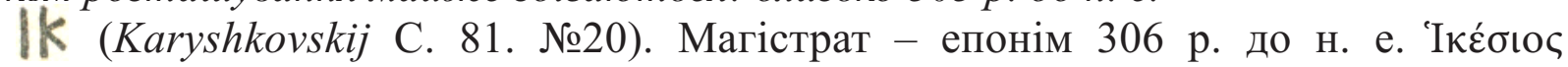

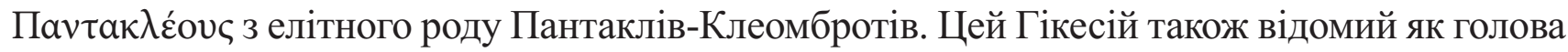

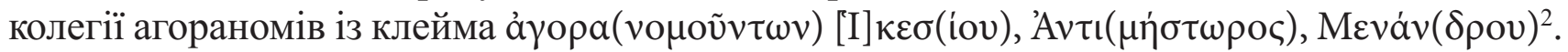
Про співвідношення диферента № 20 з подібним до нього № 49 див. нижче.

Датування $з$ урахуванням порядку розташування майже збігається 3 просопографічним датуванням: близько 302 р. до н. е.

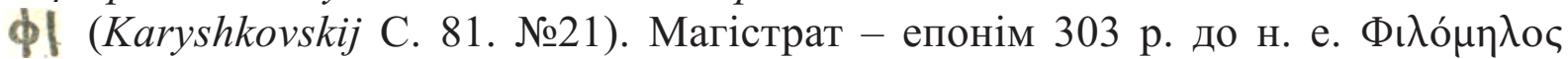
$\Delta$ lovvбíov $з$ найпотужнішого роду Діонісіїв (рис. 1). Датування просопографічне майже збігається з датуванням за порядком розташування у групі: близько 301 р. до н. е.

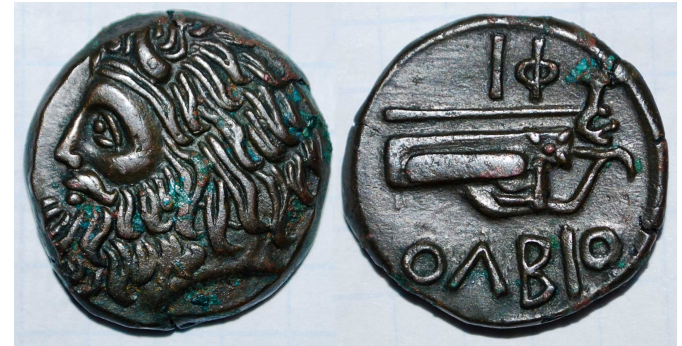

Рис. 1. «Борисфен» магістрата

Філомила Діонісіїва, який був епонімом у 303 р. до н. е.

Отже, чотири (або $n$ 'ять) із семи диферентів другої групи «борисфенів» концентруються у вузький хронологічній ділянці епонімного каталогу за 306, 305, 304, 303 рр. до н. е. Решта з трьох (або двох) диферентів не ідентифіковано з епонімами. Тим самим, по-перше, підтверджується гіпотеза П. О. Каришковського про перерву між групами I $i$ II. Ця перерва складала приблизно п'ятнадиять років. По-друге, можливо звузити до 307301 рр. до н. е. датування другої групи «борисфенів», яке П. О. Каришковський відносив до кіния IVпочатку III cm. до н. е. Немає будь-яких підстав, за В. О. Анохіним, вважати другу групу однорічною емісією із шести магістратів. Так, відмічений дослідником ${ }^{3}$ спільний лицьовий штемпель до диферентів 8 та $N$-перехідний від невідомого магістрата до

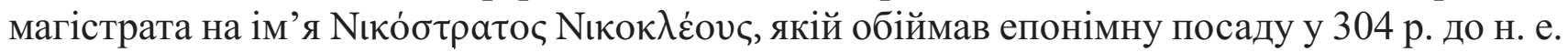
Далі диференти $\mid \mathbb{k}$ та $\$$ | на спільному лицьовому штемпелі пов'язуються з посіданням магістратської посади послідовно Гікесієм Пантакловим та Філомилом Діонісієвим, які були епонімами, відповідно, у 306 та 303 рр. до н. е.

Група III (Karyshkovskij C. 81. №№ 22-27). Просуваючись нижче й зіставляючи диференти третьої групи «борисфенів» 3 епонімним каталогом, починаючи 3300 р. до н. е. аж до 291 р. до н. е. (останній рік перед початком хронологічної лакуни), будь-яку кореляцію виявити не вдається. Цим, по-перше, підтверджується гіпотеза П. О. Каришковського про наявність перерви в карбуванні між II і III групами не суперечить гіпотезі цього дослідника 5 про датування «борисфенів» третьої групи кордоном першого та другого десятиліття III ст. до н. е. Ізольоване положення третьої

\footnotetext{
Див.: Ніколаєв М. І. Ономастика та просопографія... С. 14. Взагалі, відзначимо виняткову складність інтерпретації монограм (скорочень), що пов'язані з розповсюдженими іменами на API $\Sigma$..

Николаев Н. И. Агораномы эллинистической Ольвии... С. 392-406.

3 Анохин В. А. «Борисфены» и их место... С. 21, рис. 14.

${ }^{4}$ Karyshkovskij C. 82.

Karyshkovskij C. 82
} 
групи, яка не дала перехідних лицьових штемпелів у суміжні групи, відзначав В. О. Анохін ${ }^{1}$. Отже, з урахуванням епонімного каталогу хронологічний орієнтир початку карбування третьої групи: terminus post quem - 290 р. до н. е.

Головною проблемою нашого подальшого дослідження виступає наявність хронологічної лакуни в епонімному каталозі Ольвії IPE I² 201 в діапазоні 290-227 рр. до н. е., тому детально розглянемо головні принципи та особливості таких досліджень. Просопографічні дослідження в лакуні стали доступними завдяки спеціальним інструментам, але, безумовно, мають тенденцію до більшої гіпотетичності та зниження хронологічної точності. Виконання таких досліджень грунтується на збережених фрагментах синхронізованого епонімного каталогу (як у нижній, так і в горішній частині), можливості реконструкції родових стем головних родів (згідно з законом генеалогії), властивостях теоретичної моделі міської громади ${ }^{2}$ (зокрема, родовий протекціонізм із займаної посади та, відповідно, наслідування монограм, епонімні квоти тощо), застосуванні просопографічної інформації із групи порівняно точно датованих лапідарних написів, агораномних клейм та гир а також пошуку кореляції з легендами інших монетних випусків, зокрема на сріблі. Так, на срібних монетах присутня велика кількість скорочень імен магістратів: АГА, $\triangle \mathrm{HMH}$, IP, MOI, MON, ФI $\Lambda$, $\Upsilon \mathrm{M}, \Pi \mathrm{O} \Lambda \Upsilon, \Pi K \mathrm{P}, \Sigma \mathrm{I}, \Sigma \mathrm{TP}, \mathrm{XAIP,} \mathrm{EPA.}$ На жаль, більшість із них не піддається просопографічній інтерпретації. Втім, існує й декілька достатньо виразних примірників: $\Sigma \Upsilon \mathrm{M}, \mathrm{AГА}, \Delta \mathrm{HMH}, \mathrm{XAIP}, \Phi \mathrm{I} \Lambda^{3}$, ПО $\Upsilon \Upsilon, \mathrm{MON}^{4}$. Історичні особи, що згадуються в цих пам'ятках, напевно, у суміжні роки обіймали епонімну, магістратську та інші посади.

У дослідженні хронологічної лакуни каталогу важлива інтерпретація скорочення АГА, та, відповідно, - декрету на честь синів херсонесита Аполлонія ${ }^{5}$, декрет традиційно пов'язують з виникненням фінансової кризи наприкінці першої чверті III ст. до н. е. В. О. Анохін ${ }^{6}$ інтерпретує скорочення АГА як таке, що пов'язане 3 ім'ям

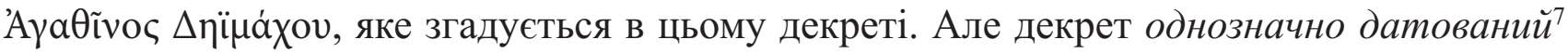
215 р. до н. е. Відповідно, на сьогодні він уже не може вважатися епіграфічним свідоцтвом фінансової кризи ${ }^{8}$ другої чверті III ст. до н. е. Декрет - складник грошово-економічної реформи передостаннього десятиліття III ст. до н. е. Що стосується срібних монет зі скороченням АГА, то найбільш вірогідне їх датування - початок другої чверті III ст. до н. $\mathrm{e}^{9}$.

Також, як приклад, дослідимо у хронологічній лакуні каталогу рід Нікератів - однієї iз семи елітних ольвійських родин. Фрагмент стеми роду III ст. до н. е. запропонований В. В. Латишевим ${ }^{10}$ і з урахуванням сучасних доповнень представлений у монографіï ${ }^{11}$. Одне з поколінь братів - синів Нікерата - належить до рубежу першої та другої чверті III ст. до н. е. Так, у скороченні на сріблі XАIP (Nechitailo № 361; Anokhin № 400) приховано родове ім'я Нікератів - Хаıри́ обіймав й епонімну посаду. У будь-якому разі, його однойменний онук Хаıри́

\footnotetext{
Анохин В. А. «Борисфены» и их место... С. 23.

2 Николаев Н. И. Развитие просопографической модели общины небольшого античного города (на примере Ольвии). Древние цивилизации: социум и человек. Отв. ред. В. В. Дементьева. Ярославль. 2018. С. 99-104.

Див. лему до диференту № 23.

${ }^{4}$ Скорочення на сріблі MON (Nechitailo № 355), ймовірно, належить другорядному роду Монімів та є спрощеним наслідуванням скорочення на мідній монеті MONI (Nechitailo № 106). Див.: Николаев Н. И. Просопография Ольвии... С. 275

Николаев Н. И. Просопография Ольвии... С. 273.

${ }^{6}$ Анохин В. А. Монеты античных городов Северо-Западного Причерноморья. К. 1989. С. 41.

Останніми роками просопографічне датування декрету IOlb 28+29+123+IPE I 240 здобуло підтвердження з боку херсонеського амфорного клеймування у варіанті, запропонованому V. F. Stolba. Див.: Николаев Н. И. Ольвийские декреты в честь граждан Херсонеса в контексте локальных хронологий Ольвии, Херсонеса и Понтийского царства. Аристей. Вестник классической филологии и античной истории. 2017. XV. C. $55-76$.

${ }^{8}$ Stolba V. F. Monetary Crises in the Early Hellenistic Poleis of Olbia, Chersonesos and Pantikapaion. A Re-assessment, in: C. ALFARO, C. MARCOS \& P. OTERO (eds.), XIII Congreso Internacional de Numismática (Madrid, 2003). Actas - Proceedings - Actes. Madrid (2005). C. 396.

${ }^{9}$ Николаев Н. И. Агораномы эллинистической Ольвии... С. 392-406.

${ }^{10} I P E \mathrm{I}^{2}$ C. 209.

${ }^{11}$ Николаев Н. И. Просопография Ольвии... С. 270-271.
} 
Nıкпра́тоv обіймав цю посаду приблизно через 60 років - у 221 р до н. е. Відповідно, з'являються підстави для побудови хронологічної моделі життєдіяльності Хайримона I монетного магістрата XAIP: у першому наближенні пік його активності припадає на

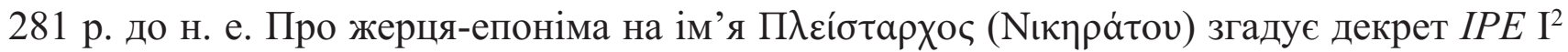
32 на честь Протогена. Розрахунковий пік його активності - 277 р. до н.е $\mathrm{e}^{1}$. Ще одним

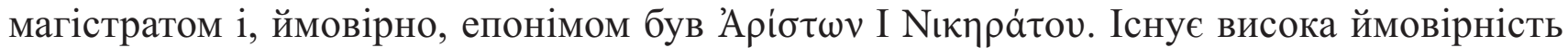
того, що скорочення API і AP на «борисфенах» групи IV (Karyshkovskij C. 81. №33, 34) стосуються Аристона I Нікератова, відповідно, вони датуються близько 267 р. до н. е. Графічні аналоги скорочень №o 33, 34, що 3’являються через два покоління (див. диференти №№ 91, 92), ймовірно, згідно з традицією наслідування, ідентифікуються 3 епонімом 218 р. Аристоном II Нікератовим, братом епоніма 221 р. до н. е. Хайримона II Нікертова.

Належачи до вищої еліти поліса, Нікерати, зокрема, дотримувалися звичаїв виконання епонімії з допомогою епонімних квот: рідні брати з одного покоління роду Нікератів могли обіймати цю посаду за період 12 років ${ }^{2}$. Наприклад, квота Нікератів простежується у 221, 220, 218 і 210 рр. до н. е. Аналогічний період тривалістю 12 років, близько 280-270 pр. до н. е., ймовірно, охоплювала епонімія (та різні магістратури) Хайримона I (Nechitailo № 361; Anokhin № 400), Аристона I (Karyshkovskij С. 81. №33, 34) та Плістарха Нікератових тощо. Між Аристоном I, Хайримоном I, Аристоном II та

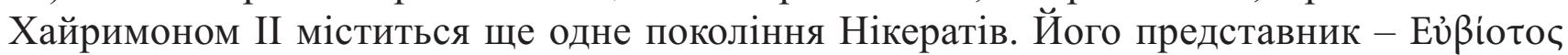

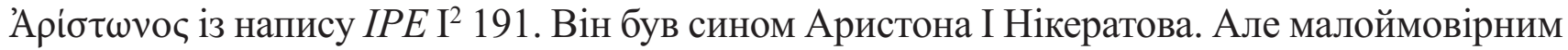

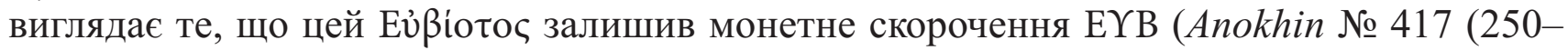
240 рр. до н. е.))3. Ще одна особа 3 цього покоління - батько епонімів 221, 220, 218 i 210 рр. до н. е., якийсь Nıки́ратос, мабуть, магістрат, що ідентифікується зі скороченням ㄴ... на «борисфені» № 60.

Важливим допоміжним інструментом досліджень у лакуні каталогу виявляється запропонований П. О. Каришковським відносний пороковий порядок розташування диферентів. Отже, із застосуванням інструментів дослідження в лакуні каталогу розглянемо диференти третьої та інших груп:

Af (Karyshkovskij C. 81. №22). Не піддається просопографічному тлумаченню.

$\Sigma \Omega$ (Karyshkovskij C. 81. №23). Простежується наслідування зі спрощенням:

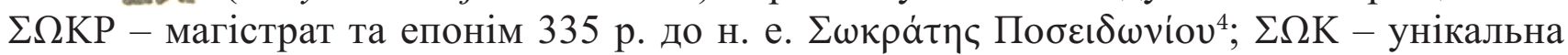
монета з головою Аполлона та лучником (приватна колекція; неопублікована); $\Sigma \Omega$ диферент № 23. Деякі паралелі нами знайдено в керамічній епіграфіці, зокрема в

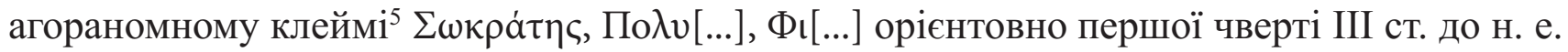

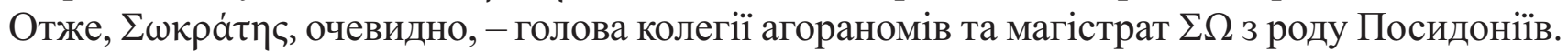
Не виключаємо обіймання цим «Сократом» епонімної посади, яка розрахунково «тяжіє» до 282 р. до н. е. Другий агораном із клейма - якийсь По $\nu[. .$.$] , ймовірно, носій імені$

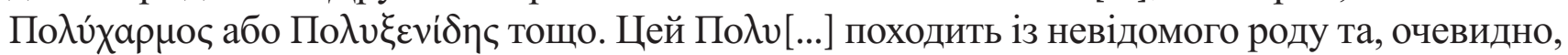
відповідає монетному магістрату По[...], який позначений диферентом №24, оскільки утворює безперервну низку диферентів (№№ 23, 24) 3 ім’ям головного агоранома

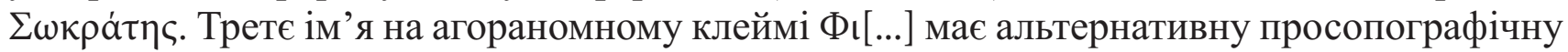
інтерпретацію6 ${ }^{6}$ Маємо підстави вважати його представником роду Посидоніїв або

\footnotetext{
Николаев Н. И. Просопография Ольвии... С. 189

Там само. С. 94-96.

3 Скорочення ЕҮВ може бути спрощеним наслідуванням скорочення ЕҮВІО, що належить роду Димоконів; відомий епонім 349 р. до н. е. $\Delta \eta \mu о к \tilde{\omega} \nu$ Ev̉ßı́tov (див. : Ніколаєв М. I. Ономастика та просопографія... С. 15). Вірогідно, скорочення ЕҮВ належить магістрату, який був епонімом

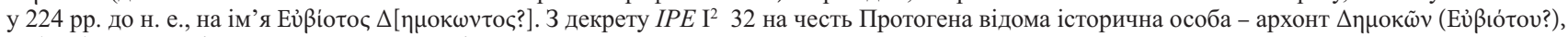

тобто батько епоніма 224 р. до н. е. та магістрата ЕҮВ.

${ }^{4}$ Ніколаєв М. І. Ономастика та просопографія... С. 18.

Рубан В. В. Магістратура агораномів в Ольвії... С. 39; Николаев Н. И. Агораномы эллинистической Ольвии... С. $392-406$.

${ }^{6}$ Там само. С. 392-406.
} 
Геродорів. Очевидно, тій же особі належить і скорочення ФІ $\Lambda$ на срібній монеті (Nechitailo № 360) ${ }^{1}$.

ПО (Karyshkovskij С. 81. №24). Інтерпретація диференту № 24, як і попереднього,

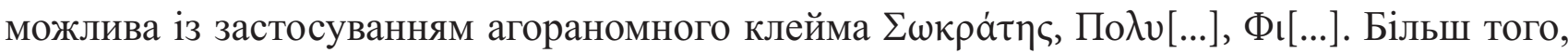

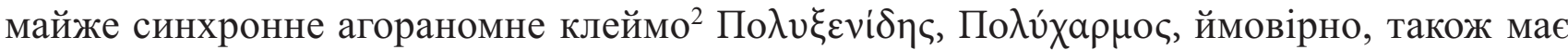
просопографічний зв’язок із диферентом № 24. На жаль, у даному разі ризик інтерпретації високий ${ }^{3}$.

Не виключаємо, що срібні монети (див. нижче) зі скороченням ПО $\Upsilon$ стосуються історичної особи, яка прихована за диферентом № 24 та в агораномних клеймах

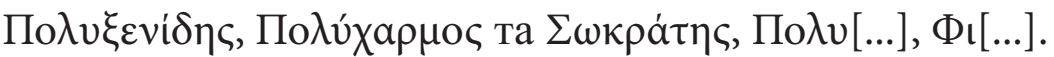

E (Karyshkovskij C. 81. №25). У монограмі можливо прочитати початкові літери імені; Пє... або Ел.... Отже, у першому варіанті за монограмою, ймовірно, приховане

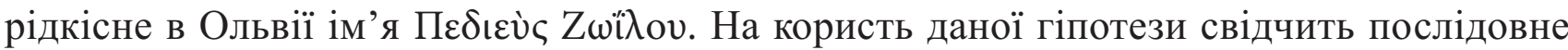
обіймання Педеєм посади агоранома та голови колегії агораномів - клейма на мірних

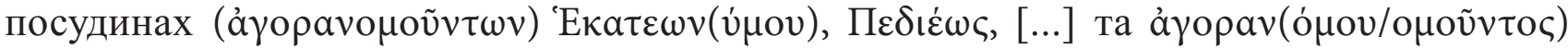

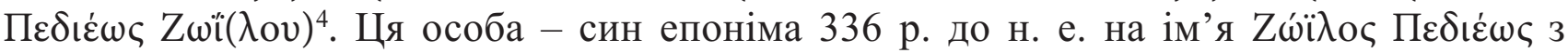
другорядного роду Педеїв. Хронологічно більш бажана інтерпретація диференту № 25 із

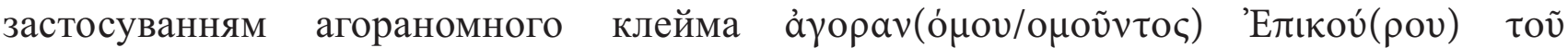

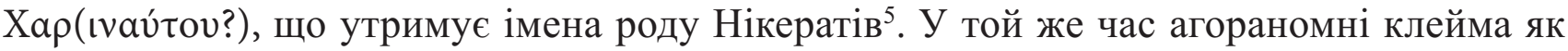
Педея, так і Епікура мають додаткове анепіграфне клеймо із зображенням восьминога, тобто вони порівняно синхронні.

A (Karyshkovskij C. 81. №26). Диферент утримує літери: чи то $\Lambda$ а..., чи то Ма....; його інтерпретація майже неможлива. Нещодавно В. М. Орликом ${ }^{6}$ опублікований подібний до зазначеного диферент, однак він приналежний до останніх груп. Отже, розглядаючи диференти №№ 26, 27, 33, 34 спільно з диферентами №№ 90, 91, 92 ma новим екземпляром, можливо зробити попередній висновок про їхнє родове наслідування. Разом з тим такий стійкий «тандем» диферентів потребує подальших досліджень.

¿Y (Karyshkovskij C. 81. №27). До розгляду диференту долучаємо срібну емісію 280-270 pр. до н. е. (Anokhin №№ 387-401) чи навіть 270-240 рр. до н. е. (Nechitailo №№ 351-363), про яку ми вже коротко згадували. До диференту $\Sigma \Upsilon$ близьке скорочення на сріблі $\Sigma \Upsilon M-\Sigma u ́ \mu \mu а х о \varsigma^{7}$. Це характерне ім’я Діонісіїв. Наприклад, відомий епонім 316 р. до н. е. $\Sigma u ́ v \mu a \chi о \varsigma^{8} \Delta$ tovvбíov. Пропонуємо гіпотезу про синхронність срібних монет $\Sigma \Upsilon$ та «борисфенів» $\Sigma \Upsilon$ К. Крім того, згідно з традицією наслідування можлива гіпотеза про спорідненість магістрата $\Sigma \Upsilon \mathrm{M}(\Sigma \Upsilon)$, якій діяв близько 280-270 рр. до н. е., 3 магістратом останньої групи $\Sigma \Upsilon M$ (Karyshkovskij С. 81. №90). Відповідно, згідно 3 законом генеалогії датування «борисфену» 3 диферентом № 90 «тяжіє» до 220-х рр. до н. е.

Підсумовуючи дослідження диферентів групи III, треба вказати на приблизність датувань: terminus post quem - 290 р. до н. е., terminus ante quem - 271 р. до н. е. (на грунті попередньої хронології груп IV-VI). Саме цей орієнтир створює головну похибку нашої хронологічної моделі в лакуні каталогу та впливає на подальші хронологічні розвідки,

' Вірогідну інтерпретацію скорочення ФІ $\Lambda$ становить наслідування скорочення ФІАІ, яке належить представнику Геродорів, епоніму 345 р. до

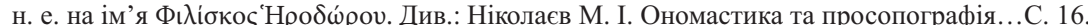

Рубан В. В. Магістратура агораномів... С. 39; Николаев Н. И. Агораномы эллинистической Ольвии... С. $392-406$.

Втім, скорочення ПО - не наслідування скорочення ПО ЕЕ. Див.: Ніколаєв М. І. Ономастика та просопографія... С. 15.

${ }^{4}$ Николаев Н. И. Агораномы эллинистической Ольвии... С. 392-406.

Рубан В. В. Магістратура агораномів в Ольвії... С. 30-40.

${ }^{6}$ Орлик В. М. До питання існування грошового обігу на території Дніпровського Правобережного лісостепу (V-I ст. до н. е.). Історія, археологія, інформаційна, бібліотечна та архівна справа: актуальні проблеми науки та освіти: тези доповідей I Міжнародної наукової конференції, 13 травня 2020 р. Кропивницький, 2020. 184 с. Також, див.: Anokhin № 467; можливо, повторне посідання посади магістрата.

Карышковский П. О. Монетное дело... § 16.

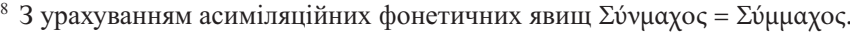


зокрема, призводить до ймовірного заниження хронології IV, V, VI груп «борисфенів». Пам'ятаючи, щзо наше завдання передбачає отримання лиме попередньої (очінної) хронологіі, можливо сформулювати напрям подальших розвідок, зокрема, пов'язаний $з$ використанням корелячії між патронімами епонімів 220-208 рр. до н. е. та монограмами групи V (див. нижче).

Виявлена В. О. Анохіним ${ }^{1}$ послідовність із двох диферентів $\mathcal{A}$ та $\Sigma \Omega$ на спільному лицьовому штемпелі, як і в групах I та II, - перехідна від невідомого магістрата

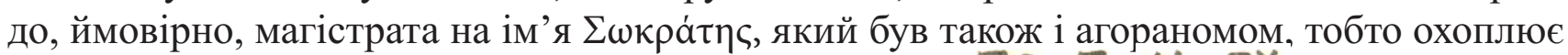
два роки. Складніше інтерпретуються диференти ПО Е $\mathrm{A} \Sigma Y$ на спільному лицьовому штемпелі. На нашу думку, таке поєднання диферентів виникло завдяки застосуванню в Ольвї відомої в античній монетній справі технологї, яка передбачала використання кількох однотипних лицьових штемпелів, розташованих поряд на ковадлі . Безумовно, нам невідомі принципи, якими керувалися монетарії під час застосування того чи іншого лицьового штемпеля, але така технологія забезпечувала умовно рівномірне їхнє зношення; своїм наслідком вона мала появу монет із різними комбінаціями диферентів, пов'язаними спільними лицьовими штемпелями, упродовж кількох років, зокрема у нашому випадку - чотирьох років. Зауважимо, що В. О. Анохін наводить приклад існування спільних лищьових штемпелів для монет Тіри упродовж n'яти - восьми років ${ }^{3}$.

Група IV (Karyshkovskij C. 81. №№ 28-40). Переходячи до четвертої групи, варто зазначити, що П. О. Каришковським ${ }^{4}$ установлена щорічна емісія IV, V та VI груп безперервно упродовж 37 років, яка датується вченим із кінця 80-х і до початку 40-х рр. до н. е. Отож, розгляд ичих трьох груп можливо виконати як розгляд одного ичілого із залученням відносних датувань; ие треба розглядати як додатковий інструмент дослідження.

I I (Karyshkovskij C. 81. №28, 29). Існує багато імен, що відповідають початковим літерам імені Нр... Раніше, з огляду на родові традиції Протогенів, зокрема обіймання посади монетного магістрата, ми пропонували гіпотезу, за якою диференти №№28, 29

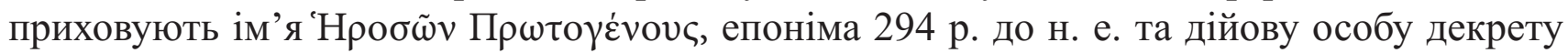
IPE $\mathrm{I}^{2} 32$ - батька Протогена ${ }^{5}$. Втім засмучує хронологічна відстань між виконанням обов'язків епонімії (294 р. до н. е.) та магістратської посади. До того ж під час виконання обов’язків посади епоніма Геросонтом емісія «борисфенів» не проводилася.

Отже, розглянемо, на жаль, непереборні, альтернативні варіанти інтерпретації диферентів №№ 28, 29. Перший. Декрет IPE I² 32 на честь Протогена згадує жерця-

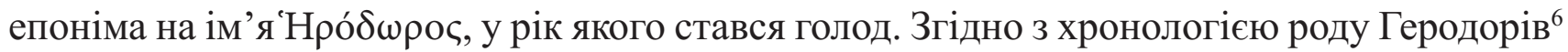
цей рік «тяжіє» до 267 р. до н. е.; відповідно, за порядком розташування (див. нижче) диференти №№ 28, 29 датуються 270 р. до н. е., тобто, роки, практично, збігаються.

Другий. Не менш вірогідне, згідно з традицією наслідування посади від батька до сина (див. наступний диферент № 30), ототожнення монограм №№ 28, 29 з батьком

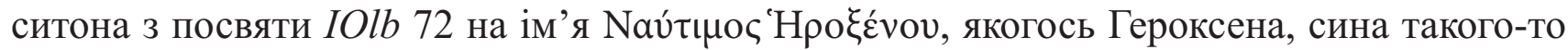

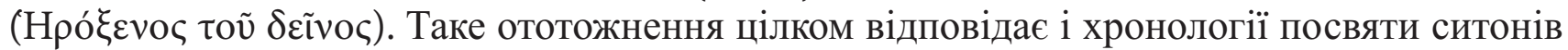
(256-245 рр. до н. е.). Утім, ризик ототожнення диферентів №№ 28, 29 достатньо високий. Диференти №№ 28, 29 мали спільний лицьовий штемпель, але, безумовно, належать

\footnotetext{
Анохин В. А. «Борисфены» и их место... С. 21, рис. 14

Зограф А. Н. Античные монеты... С. 31; Карышковский П. О. Монетное дело... С. 34-35. До речі, П. О. Каришковський повідомляє про існування «борисфена», що підтверджуе застосування вказаної технології.

3 Анохин В. А. Монеты... С. 91.

${ }^{4}$ Karyshkovskij C. 82 прим.

${ }^{5}$ Николаев Н. И. Просопография Ольвии... С. 186.
}

там само... C. 200 
до однорічної емісії. Диференти №№ 28, 29 за порядком розташування датуються 270 р. до н.е ${ }^{1}$.

NA (Karyshkovskij C. 81. №30). Імена з початковими літерами a... у догетській Ольвії залишаються маловідомимиㄹ. Найбільш ймовірна просопографічна інтерпретація

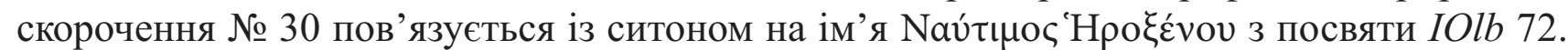
Він походить із невідомого роду. 3 огляду на варіант інтерпретації попереднього

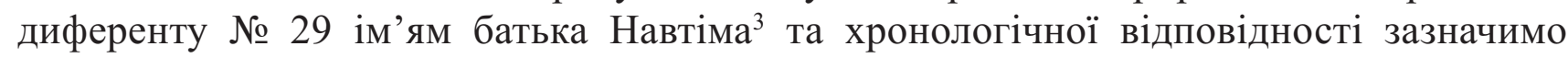
ймовірність пропонованої інтерпретації. Цій гіпотезі не заважає навіть те, що Навтім на рельєфі з посвяти ситонів виглядає начебто молодим чоловіком ${ }^{4}$ (див. рис. 2. Навтім зображений другим зліва); посвята ж ситонів датується близько 256-245 рр. до. н. е. Диферент № 30 за порядком розташування «тяжіє» до 269 р. до н. е.

A A (Karyshkovskij C. 81. №31, 32). Як варіант інтерпретації, магістрат ’Аฑ́vaıь Кóvwvoৎ з роду Батаків - одна з дійових осіб посвяти ситонів IOlb 72. Батько цього Афінея

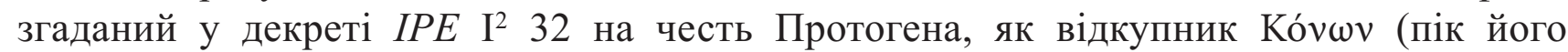
активності ${ }^{5}-280$ р. до н. е.). Відомо, що цей другорядний рід також брав участь у монетній справі. Диференти № 31 та № 61 розкриваються літерами А $\theta$..., але мають різне графічне зображення, тому, ймовірно, належать до неспоріднених осіб. Датування диферентів №№ 31, 32 за порядком розташування - 268 р. до н. е.

API AP AP (Karyshkovskij C. 81. №o33, 34). Уводимо новий варіант диференту. Аналогічна диферентам №o 33, 34 послідовність представлена й диферентами №№ 91, 92, що, очевидно, становить традицію наслідування. Згідно із сучасними уявленнями 6

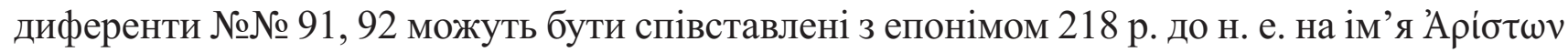
Nıкпра́тov 3 роду Нікератів. Водночас, згідно 3 законом генеалогії та традиції наслідування, диференти №№ 33, 34 (API, АР), ймовірно, належать дідові даного епоніма. Пік активності цього Аристона - магістрата та епоніма, за спрощеною схемою розрахунку «тяжіє» до 278 р. до н. е. Датування монет із диферентами №o 33, 34 за порядком розташування -267 р. до н. е.

EK(Karyshkovskij C. 81. №35). Ймовірно, скорочення розкривається розповсюдженим в Ольвії ім'ям Екатє่ $\omega v$, яке притаманне родам Пантаклів-Клеомбротів та Аристократидів ${ }^{7}$. Втім, альтернатива не виникає; вище нами встановлено, що в роду Пантаклів-Клеомбротів вживалися складні монограми 3 цим іменем, наприклад, Karyshkovskij C. 81. №o13, 14, які позначають епоніма 320 р. до н. е. та магістрата на

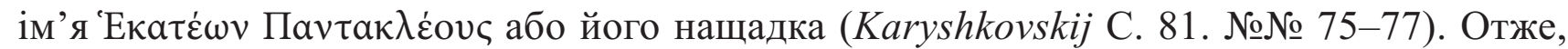
скорочення № 35, очевидно, належить до Аристократидів. Дану гіпотезу підтверджують й історичні обставини: початок загострення кланової боротьби у 260-ті рр. до н. е. між Діонісіями та Аристократидами й подальше домінування Аристократидів в Ольвії упродовж майже двох десятиліть ${ }^{8}$. За порядком розташування скорочення № 35 датується 266 р. до н. е.

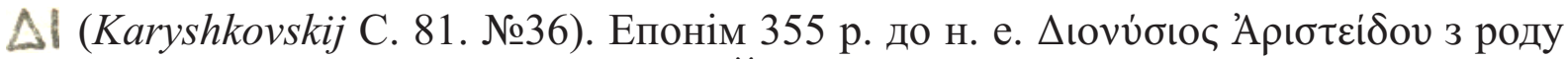
Діонісіїв залишив скорочення $\Delta \mathrm{IO}(\mathrm{N})^{9}$. Ймовірно, диферент $\Delta \mathrm{I}-$ це спрощене

${ }^{1}$ Вірогідно, монети ОI ЕПТА (Anokhin № 404) з епонімною датою у вигляді диферента № 28 також близькі до 270 р. до н. е.

2 Так, ім’я Navvã с належить особі з невідомого роду з двох магічних переліків рубежу IV-III ст. до н. е. Див.: IGDOlb 110; Belousov A., Dana M., Nikolaev N. Deux nouvelles defixionum tabellae du territoire d'Olbia du Pont. Zeitschrift für Papyrologie und Epigraphik. 2016. Bd. 197. S. 167-177.

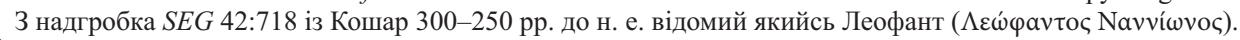

Протекція за схемою «батько $\rightarrow$ син», у якій, безумовно, син за віком - молода особа, досить поширена. Див.: Николаев Н. И. Просопогрфия Ольвии... С. 64-66.

4 У всякому разі, так припускають Г. С. Русяєва та М. В. Русяєва, автори науково-популярного видання «Ольвія Понтійська. Місце щастя та печалі» (С. 130).

${ }^{5}$ Николаев Н. И. Просопография Ольвии... С. 200.

6 там само... С. 218-222.

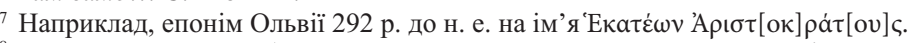

${ }^{8}$ Николаев Н. И. Борьба кланов в Ольвии IV-III вв. до н.э. Stratum plus. 2018. № 6. С. $73-87$.

${ }^{9}$ Ніколаєв М. І. Ономастика та просопографія у відновленні монетних монограм... С. 16. 
наслідування скорочення $\Delta \mathrm{IO}(\mathrm{N})$. Особливість роду Діонісіїв в догетській Ольвії полягала у передачі родових імен від батька до сина $-\Delta$ เovv́бıৎ $\Delta$ เovvoíov ${ }^{1}$. Це ускладнює ідентифікацію скорочення. Втім, розглядаючи подібні та хронологічно близькі скорочення №36 та № 42, можливо запропонувати гіпотезу про їхнє тлумачення на основі синхронного декрету $B C H$ 1928: 52 Дельфійського святилища Аполлона на честь, зокрема, проксена та евергета, ольвіополіта Діонісія, сина Діонісія, що датується 252251 рр. до н. е. Водночас скорочення №36 стосується батька, а скорочення №42, відповідно, стосується сина 2 . 3 урахуванням подій кланової боротьби та тимчасової поразки Діонісіїв у боротьбі з Аристократидами ${ }^{3}$ датування «борисфенів» із диферентами №36 та 42 «тяжіє» до 260 pр. до н. е. Безумовно, це лише одна з гіпотез, яка відповідає хронології. Диферент № 36 за порядком розташування датується 265 р. до н. е.

OE (Karyshkovskij C. 81. №37). Очевидно, диферент є спрощеним наслідуванням

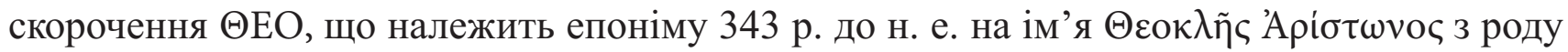

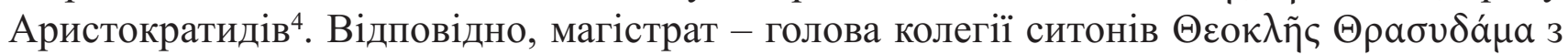
роду Аристократидів (посвята $I O l b$ 72, близько 256-245 pр. до н. е.). 3 огляду на традицію перевищення віку голови колегії на 10-15 років щодо рядових членів ${ }^{5}$ така гіпотеза відповідає хронології. Диферент № 37 за порядком розташування датується 264 р. до н. е.

У підсумку нами запропоновані гіпотези про інтерпретацію диферентів №№ 2829, 30, 31-32 та 37 (тобто, у межах діяльності одного покоління) іменами дійових осіб колегії ситонів із посвяти IOlb 72 та їхніх батьків (рис. 2).

HГ H (Karyshkovskij C. 81. №38). Уводимо новий різновид диференту 3 розділеними літерами Н та Г. Як варіант, у монограмі читається рідкісне в Ольвії ім'я 'Нүท́ $\mu \omega v$. Просопографічна інтерпретація диференту неможлива. Диферент № 38 за порядком розташування датується 263 р. до н. е.

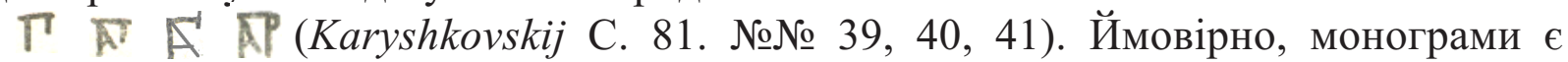
наслідуванням скорочення ПАР 6 , що згідно з нашою гіпотезою приховує батька епоніма

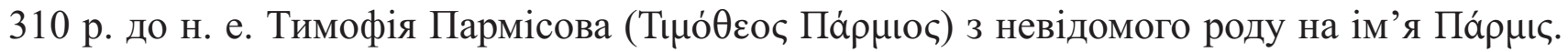
Відповідно, слідом за П. О. Каришковським ${ }^{7}$, пропонуємо обережну гіпотезу про те, що в монограмах №№ 39, 40, 41 також приховане ім’я Па́ $\mu \mu \varsigma^{8}$. Усупереч тенденції до поступового спрощення монограм у випадку з послідовністю №№ 39, 40, 41 спостерігається їх поступове ускладнення. Безумовно, причини такого ускладнення невідомі, втім, здогадки, як вважав В. В. Латишев ${ }^{9}$, можуть знайтися в кожного. Датування диферентів №№ 39, 40, 41 за порядком розташування - близько 262 р. до н. е.

Спільні лицьові штемпелі, зокрема A A EK $\triangle$ IAP та APIOE H до чотирьохрокових емісій, відповідно, послідовність EK $\triangle$ I API AP - до трьохрокової.

Група V (Karyshkovskij C. 81. №41-68). Важливим інструментом просопографічних досліджень у хронологічній лакуні каталогу за 290-227 рр. до н. е. виступає використання патронімів епонімів другого стовпия епонімного каталогу за 226-200 рр. до н. е. Розглянемо один із прикладів реалізації цього інструменту. Отже, каталог IPE I² 201 згадує епоніма 217 р. до н. е. Міса Боспорихова (Ми̃ Вобторі́хо). 3 огляду на рідкісність імені Боспорих в Ольвії скорочення ВО $\Sigma$ (диферент № 68 групи V)

\footnotetext{
Див.: IPE $\mathrm{I}^{2}$.

Втім, можливий варіант віднесення обох диферентів до батька чи до сина.

${ }^{3}$ Николаев Н. И. Борьба кланов в Ольвии... С. 73-87.

${ }^{4}$ Ніколаєв М. І. Ономастика та просопографія... С. 17.

5 Николаев Н. И. Развитие просопографической модели общины небольшого античного города (на примере Ольвии)... С. 99-104.

${ }^{6}$ Ніколаєв М. І. Ономастика та просопографія... С. 15.

7 Карышковский П. О. Монетное дело... § 16.

8 Як підтвердження: нещодавно на вітчизняному аукціоні був проданий «борисфен» із наведеним вище варіантом монограми, у якому читається

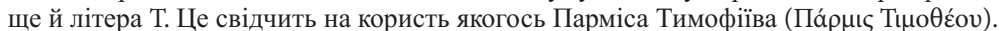

Див.: IPE $\mathrm{I}^{2}$.
} 


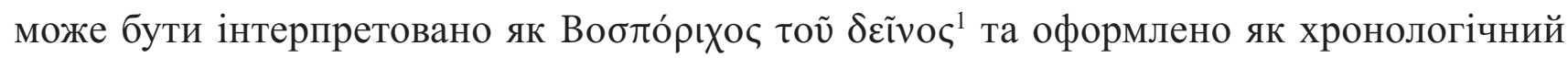
(просопографічний) факт: пік активності ймовірного епоніма та магістрата $\mathrm{BO} \Sigma$ орієнтовно «тяжіє» до 247 р. до н. е.

Звертаємо увагу читача на новий факт: включно із магістратом Боспорихом патроніми великої групи епонімів 220-208 рр. до н. е. також корелюють із диферентами «борисфенів», компактно охоплюючи другу половину випусків n'ятої групи. Зокрема, це диференти №№ 57, 59, 60, 65, 66, 68, 69, 75-76, які й розглянемо за порядком їх розташування ${ }^{2}$.

$\Delta$ l (Karyshkovskij C. 81. №42). Ще одне спрощене наслідування скорочення $\Delta \mathrm{IO}(\mathrm{N})^{3}$ (див. інтерпретацію скорочення № 35). Датування диференту № 42 за порядком розташування - близько 261 р. до н. е.

A^ (Karyshkovskij C. 81. №43). Вірогідна інтерпретація диференту як спрощене наслідування скорочення А $\Lambda \Phi$, що належить епоніму 342 р. до н. е. на ім'я 'А $\lambda \varphi \tilde{v} о \varsigma$

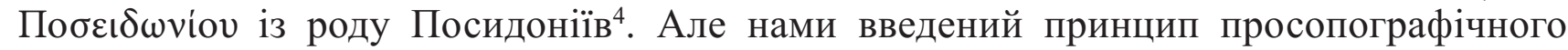
дослідження - оперувати тільки з реальними історичними особами. Саме тому за браком інформації про реальних діячів з роду Посидоніїв близько середини століття гіпотеза про інтерпретацію диференту № 43 грунтується на рідкісному в Ольвії догетського часу імені

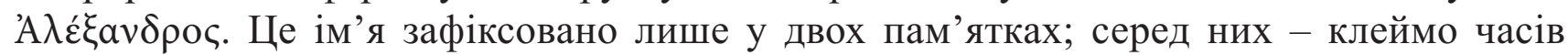

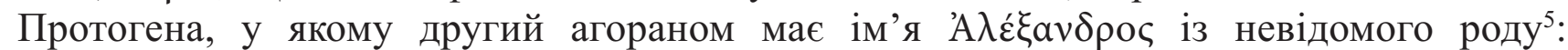

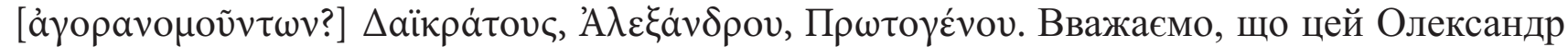
крім посади агоранома обіймав ще й посаду монетного магістрата, про що свідчать хронологічні відповідності. За допомогою простих генеалогічних розрахунків маємо можливість виконати просопографічне датування цього клейма ${ }^{6}$ одразу за двома історичними особами, Дайкрату з роду Дайкратів-Аристодимів та Протогену 3 роду Протогенів; піки активності цих осіб майже збігаються, припадаючи, відповідно, на 262 та 258 рр. до н. е. Отже, диферент просопографічно датується близько 260 р. до н. е.; інтерпретація його має достатньо високу вірогідність. Датування диференту № 43 за порядком розташування також приймаємо орієнтовно 260 р. до н. $\mathrm{e}^{7}$. 3 огляду на безперервну емісію четвертої-шостої груп можливо обчислити, щзо четверта-иоста група «борисфенів» припадає на $270^{+12}-234^{+12}$ рр. до н. е. Відповідно, умовну (але наближену до реальної) дату за порядком розташування отримують усі інші диференти четвертої-шостої груn.

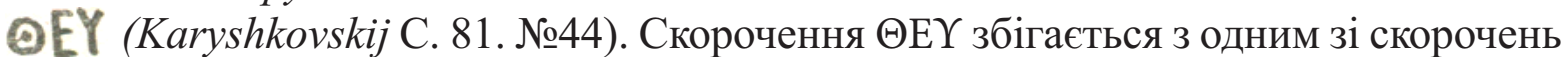

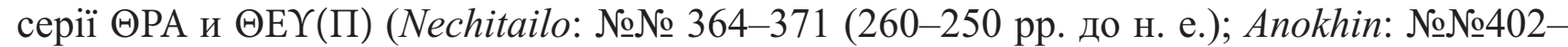

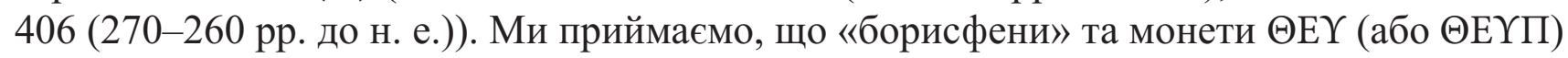

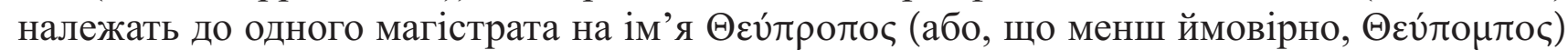

Карышковский П. О. Монетное дело... § 16.

Для оптимізаиії намої хроногічної схеми надалі бажано виконати, зокрема, прості математичні дії з мінімізації відхилень теоретичних років, щзо отримано внаслідок генеалогічних розрахунків, відносно дат, отриманих за порядком розтамування безперервної емісії групи V. Подібний алгоритм нами вже використовувався при обчисленні кількості рядків епонімного каталогу. Див. Николаев Н. И. Просопография Ольвии... частина 1.

${ }^{3}$ Ніколаєв М. І. Ономастика та просопографія у відновленні монетних монограм... С. 16.

${ }^{4}$ Ніколаєв М. І. Ономастика та просопографія у відновленні монетних монограм... С. 17.

Книпович Т. Н. Население Ольвии в VI-І вв. до н.э. Ольвия и Нижнее Побужье в античную эпоху. Под ред. В. Ф. Гайдукевича. М. ; Л. : 1956. С. 132; Николаев Н. И. Просопография Ольвии... С. 275.

${ }^{6}$ Николаев Н. И. Агораномы эллинистической Ольвии... С. 402.

Відзначимо, що це припущення становить слабку ланку нашої хронологічної моделі та створює одну з головних похибок: датування четвертоїшостої групи в нашій схемі може бути дещь занижене (максимально до 12 років). Але наше головне завдання для цієї статті полягає у подоланні альтернативи між такими, що суттєво різняться, хронологічними схемами П. О. Каришковського та В. О. Анохіна. У подальших дослідженнях ми плануємо повернутися до оптимізації оцінної хронологічної моделі. Шляхи для такої оптимізації існують. 
3 роду, пов’язаного з Аристократидами ${ }^{1}$. Датування скорочення № 44 за порядком розташування -259 р. до н. е.

AE (Karyshkovskij C. 81. №45). Відоме скорочення $\Lambda$ EONT, яке позначає

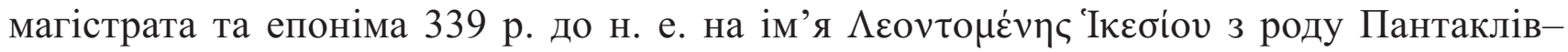
Клеомбротів ${ }^{2}$. Пропонуємо гіпотезу про те, що диферент № 45 - його спрощене

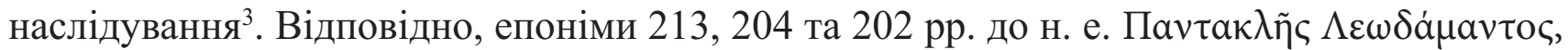

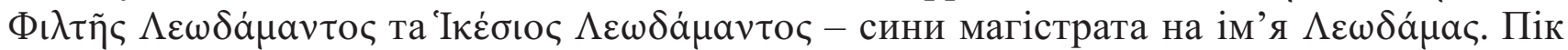
активності цього Леодамаса «тяжіє» до 262 р. до н. е. Датування диференту № 45 за порядком розташування близьке до просопографічного датування - близько 258 р. до н. е.

NoY NO (Karyshkovskij C. 81. №№ 46, 47). Скорочення підтверджують тенденцію до поступового спрощення впродовж року та позначають ім'я Novци́vıс. До речі,

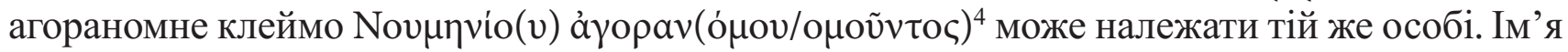
Невменій, (а втім і Леней, і Анфестерій тощо) не містить родових ознак і не становить об’єкт просопографічної інтерпретації5. Датування диферентів №№ 46, 47 за порядком розташування - близько 257 р. до н. е.

AR (Karyshkovskij C. 81. №48). Не піддається тлумаченню. За відносним датуванням диферент № 48 «тяжіє» до 256 р. до н. е.

IK (Karyshkovskij C. 81. №49). Цей диферент збігається з диферентом № 20. Зі

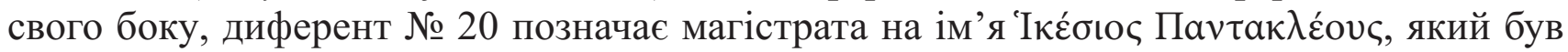

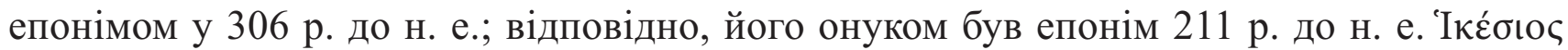

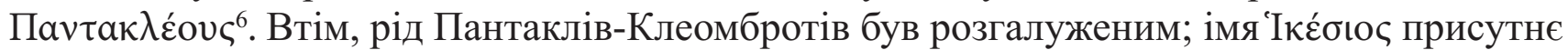

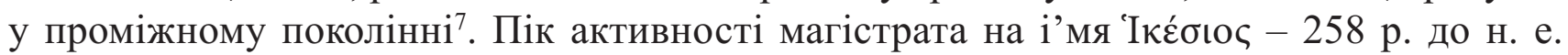
Просопографічне датування диферента № 49 майже збігається з датуванням за порядком розташування - 255 р. до н.е.

AP (Karyshkovskij C. 81. №50). Вірогідно, під цим диферентом прихований

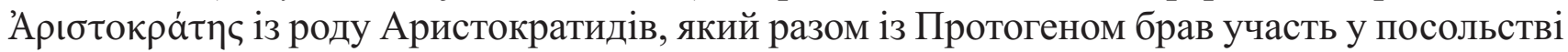
до царя Сайтафарна (див. декрет IPE $\mathrm{I}^{2} 32$ на честь Протогена). Пік активності Аристократа $^{8}-255$ р. до н. е. Останнім часом отримані відомості про молоді роки цієї особи з defixio орієнтовно першої чверті III ст. до н. е. (не опубліковане); його повне ім'я -

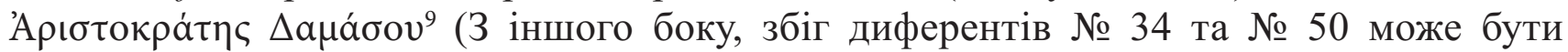
свідченням повторного обіймання магістратської посади якимось Аристоном Нікератовим із роду Нікератів. Хронологічна відстань між емісіями - 13 років, відповідно, альтернатива непереборна). Диферент № 50 за порядком розташування датується 254 р. до н. е. Це майже збігається з його просопографічним датуванням - 255 р. до н. е.

\footnotetext{
Треба згадати декрет V ст. до н. е. IGDOlb 5 на честь синопського тирана Тимесілея та його брата Теопропа з гілки Мольпагорів, яких прийняли близькі їм, мабуть, за родинним зв'язком, ольвійські Мольпагори-Аристократиди (див.: Николаев Н. И. Борьба кланов в Ольвии IV-III вв. до

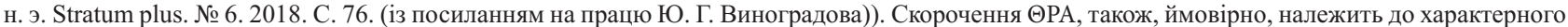

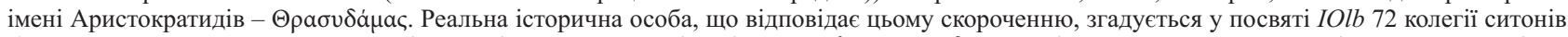

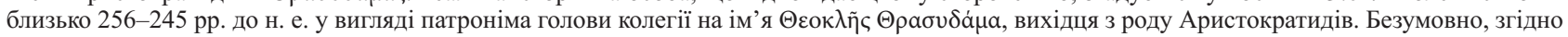

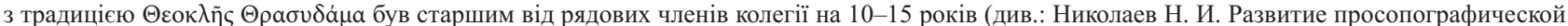
модели общины небольшого античного города (на примере Ольвии). Древние цивилизации: социум и человек. Отв. ред. В. В. Дементьева.

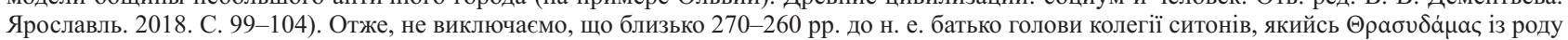
Аристократидів, обіймав посаду магістрата $\Theta Р А$.

Ніколаєв М. І. Просопографія та ономастика... С. 18.

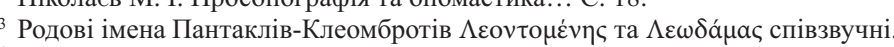

${ }^{4}$ Николаев Н. И. Агораномы эллинистической Ольвии... С. 401.

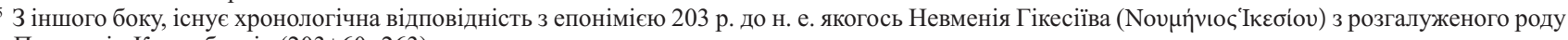
Пантаклів-Клеомбротів $(203+60=263)$.

6 Одне з формулювань закону генеалогії: на сто років припадає діяльність трьох поколінь.

Николаев Н. И. Просопография Ольвии... С. 270.

8 Там само... C. 200

Епонімна квота могутнішого роду Аристократидів (утім, як і Діонісіїв) складала 14 років; відоме двократне їі застосування (Николаев Н. И. Просопография Ольвії... С. 94-96). Вважаємо, що виконання епонімії (та/або магістратських посад) Аристократом Дамасовим близько 255 р. до н. е. та іншими представниками роду (Теоклом, Трасидамом, Теопропом тощо) також регулювалося ще однією квотою. Це означає, що скорочення $\Theta \mathrm{PA}, \Theta \mathrm{E} \Upsilon(П), \Theta \mathrm{E}$ та АР розташовані у хронологічному відрізку 14 років.
} 
Mol Mo (Karyshkovskij C. 81. № 51). Уводимо новий, спрощений варіант диференту. Інтерпретація складна. Синхронною до «борисфена», ймовірно, виступає срібна монета зі скороченням MOI (Nechitailo № 354; Anokhin № 393); вважаємо, як варіант, що обидві монети карбувались одним магістратом із невідомого роду. Втім, необхідно прийняти зауваження П. О. Каришковського ${ }^{1}$ про те, що ті зі срібних монет, скорочення на яких можливо без натяжки зіставити 3 деякими диферентами на «борисфенах», розташовані в абсолютно іншій послідовності. Датування скорочення МOI за порядком розташування - близько 253 р. до н. е.

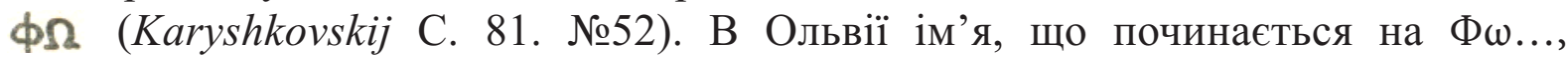
зафіксовано лише одного разу в посвяті ситонів IOlb 72, яка просопографічно датується близько 256-245 рр. до н. е. Тому просопографічна інтерпретація диференту № 523 достатньо високою вірогідністю можлива як Фи́крцтос; диферент № 52 стосується

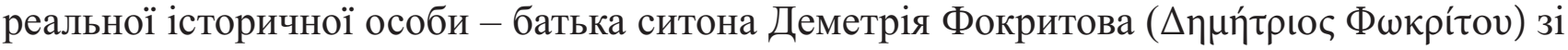
вказаної посвяти.

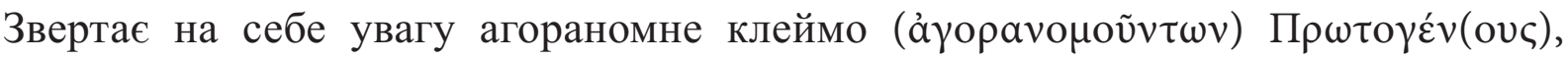

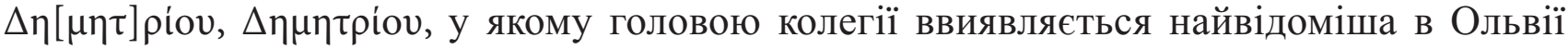

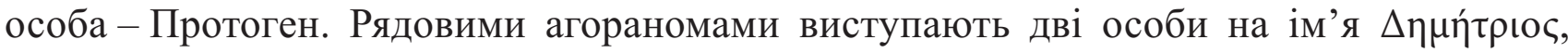
вірогідно, пов'язані родинними узами. Один із них, ймовірно, був сином магістрата Ф

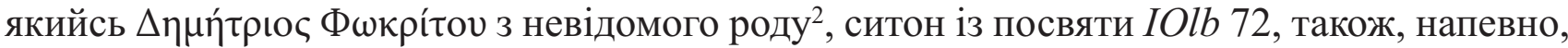
був магістратом, що випускав срібні монети з легендою $\Delta \mathrm{HMH}$ (Nechitailo №352). Датування диференту № 52 за порядком розташування - 252 р. до н. е.

Е (Karyshkovskij С. 81. №53). У монограмі № 53 читаються літери ЕП... або ПЕ.... Зовні монограма нагадує монограму № 25. Інтерпретації не піддається. Датування диференту № 53 за порядком розташування - 251 р. до н. е.

M (Karyshkovskij C. 81. №54). Диферент не піддається просопографічній інтерпретації. Датування диференту № 54 за порядком розташування - 250 р. до н. е.

主姜 (Karyshkovskij C. 81. №№55, 56). Диференти не піддаються просопографічній інтерпретації. Датування диферентів № № 55, 56 за порядком розташування - 249 р. до н. е.

低 (Karyshkovskij C. 81. №57). Магістрат, вірогідно, - батько епонімів 211 та

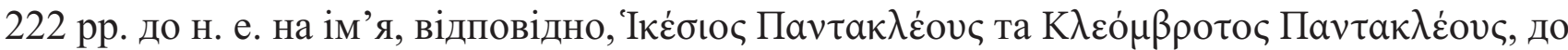

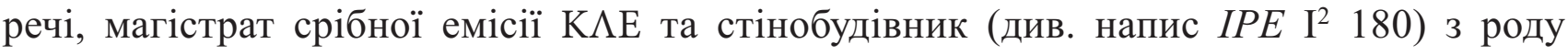
Пантаклів-Клеомбротів. Отже, розрахунковий пік активності цього Пантакла, що залишив диферент № 57, - 246 р. до н.е 3 . Просопографічне датування диференту № 57 майже збігається з датою за порядком розташування - 248 р. до н. е.

ME (Karyshkovskij C. 81. №58). Скорочення, вірогідно, відповідає родовим іменам

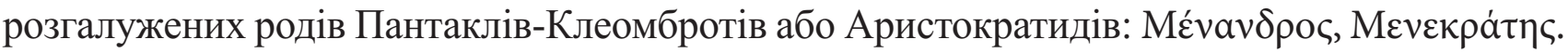
Датування диференту № 58 за порядком розташування - 247 р. до н. е.

MH (Karyshkovskij C. 81. №59). У диферентові читаються початкові літери імени

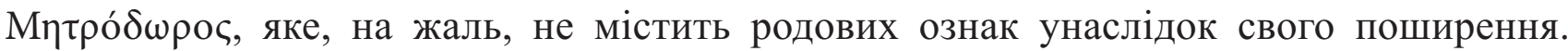
По-перше, диферент може бути наслідуванням ${ }^{4}$. По-друге, згідно 3 нашою моделлю,

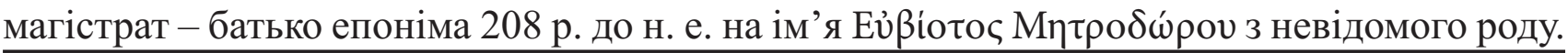

\footnotetext{
Karyshkovskij C. 83.

2 Другий агораном, Деметрій - батько епоніма 196 р. до н. е. на ім’я Еí

Утім не виключаємо, що цей самий магістрат залишив скорочення ПАN (Nechitailo № 401) на монетах серії «Деметра (Афіна) - скіфська зброя» (див. леми до диферентів № 67 та № 82). Очевидно, як традиція наслідування, існує знак епоніма на серії В乏Е (Anokhin № 486; Nechitailo

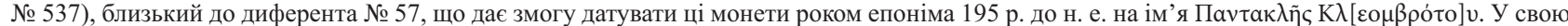

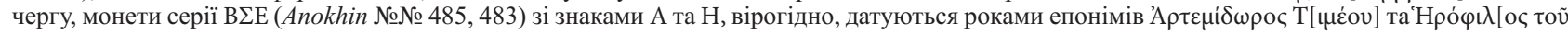
бегіvос], відповідно, 198 та 191 рр. до н. е.

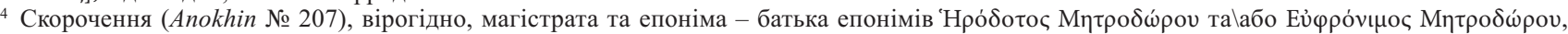
відповідно, 354 р. до н. е. та 323 р. до н. е. Див.: Ніколаєв М. І. Ономастика та просопографія...С. 16.
} 
Відповідно, пік активності Митродора (238 р. до н. е.) приблизно відповідає датуванню диферента № 59 за порядком його розташування - 246 р. до н. е.

N) (Karyshkovskij C. 81. №60). Як головний варіант, виразно читаються перші літери імені Nıки́ратоৎ, характерного для Нікератів. Ймовірно, магістрат - батько епоніма 210 р. до н. е. на ім’я Крітоৎ Nıкпра́тоv. Крит також магістрат ${ }^{1}$ срібної емісії КРI та агораном KPITOBOY². Втім, розрахунок піку активності магістрата має враховувати й епонімію всіх синів Нікерата, зокрема, Херімона, Каллікрата, Аристона та Крита, відповідно 221, 220, 218 та 210 рр. до н. е. Згідно з генеалогічними розрахунками пік активності Нікерата - 247 р. до н. е., щзо, практично, збігається з датуванням диференту № 60 за порядком його розташування - 245 р. до н. е.

А (Karyshkovskij C. 81. №61). Вірогідно, диферент - спрощене наслідування скорочення $\mathrm{A \Theta} \mathrm{H}^{3}$, що зафіксоване у IV ст. до н. е. Диферент № 61 в одному з варіантів

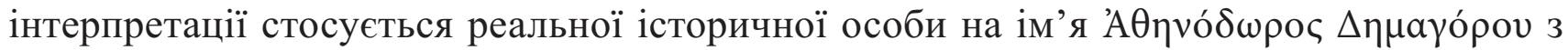
невідомого аристократичного роду; гіпотезу добре підтверджують хронологічні

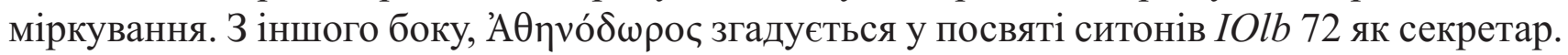
Особа, що залишила скорочення $\mathrm{A \Theta}$, також, вірогідно, залишила синхронні скорочення А $\Theta Н$ на сріблі (Anokhin № 411) та на міді (Nechinailo № 382). Датування диференту № 61 за порядком розташування - 244 р. до н. е.

Отже, нами пропонується гіпотеза, за якою майже всі члени колегії ситонів, перелічені в посвяті IOlb 72, включно з їхніми батьками ${ }^{4}$ обіймали посаду монетного магістрата (рис. 2). Це цілком зрозуміло, адже ситони входили до «економічного блоку» міської громади, так наприклад, агораномні клейма також підтверджують, що більшість ситонів обіймала посаду агоранома5

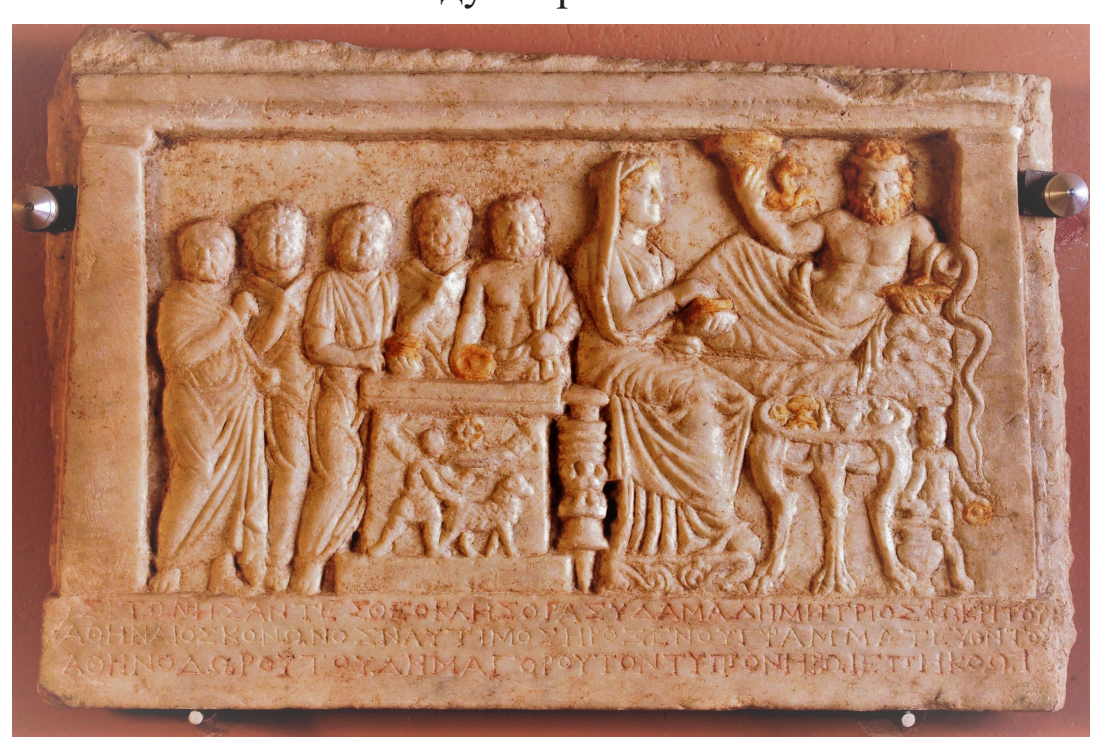

Рис. 2. Посвята колегії ситонів IOlb 72
4) W (Karyshkovskij C. 81. №№ 62, 63, 64). Диференти не піддаються інтерпретації. Їхнє датування за порядком розташування -243 р. до н. е. HP (Karyshkovskij C. 81. № 65). Має місце альтернатива, пов'язана з великою кількістю імен, що починаються на ${ }^{\top} \mathrm{H} \rho .$. Як варіант, читаємо перші

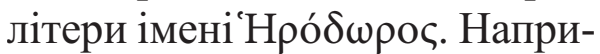
клад, припустимо, що це ім'я батька епоніма 212 р. до н. е. Стафіла Геродорова ( $\Sigma \tau \dot{\alpha} \varphi v \lambda о \varsigma$

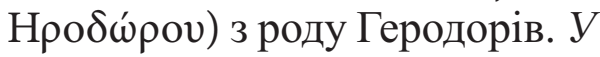
такому разі спрощений розрахунок піку активності Геродора - 242 р. до н. е., щзо абсолютно збігається 3 датуванням диференту № 65 за порядком його розташування.

Утім, допускаючи, що цей магістрат може бути жерцем-епонімом Геродором із декрету IPE I² 32 на честь Протогена, ми натрапляємо на низку питань. Так, генеалогічні розрахунки за всіма представниками роду Геродорів дають пік активності жерця Геродора

\footnotetext{
Николаев Н. И. Просопография Ольвии... С. 218. Також, див.: (Anokhin № 411; 260-250 pp. до н. е.).

Николаев Н. И. Агораномы эллинистической Ольвии ... С. 404-405.

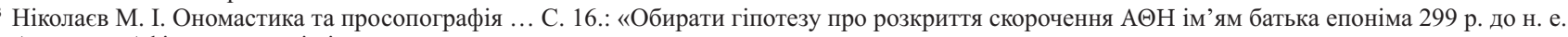
Аментора Афінодорова слід із застереженнями».

4 За винятком батька ситона Афінея Кононова, відкупника Конона.

Николаев Н. И. Агораномы эллинистической Ольвии... С. 404-405
} 
як 267 р. до н. е. (див. диференти №o 28, 29), і така дата цілком відповідає інформації 3 декрету на честь Протогена ${ }^{1}$. Очевидно, треба утриматися від просопографічної інтерпретації диференту № 65 попри хронологічні відповідності. Датування диференту № 65 за порядком розташування - 242 р. до н. е.

То (Karyshkovskij C. 81. № 66). Виразно читаються початкові літери імені, що починається на По.... Згідно з нашою моделлю, магістрат - батько епоніма 214 р. до н. е.

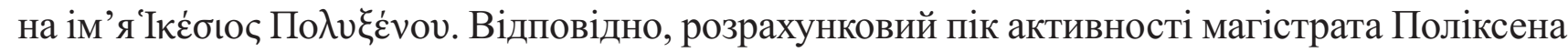
«тяжіє» до 244 р. до н. е. Датування монет із диферентом № 66 за порядком розташування - 241 р. до н. е. Це майже збігається з просопографічним датуванням.

EY (Karyshkovskij C. 81. № 67). Існує багато альтернативних варіантів інтерпретації. Втім, деяку перевагу треба надати тлумаченню скорочення як спрощеного

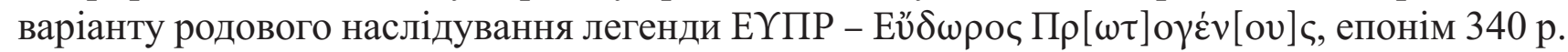
до н. е. та магістрат ${ }^{2}$. Тобто, скорочення хронологічно відповідає активності сина Протогена $з$ декрету IPE $\mathrm{I}^{2} 32$ - Свдора³ . Датування за порядком розташування - $240 \mathrm{p}$. до н. е.

Во乏 (Karyshkovskij C. 81. № 68). Починаючи розгляд групи V, ми вже зазначали, що $з$ огляду на рідкісність імені в Ольвії, монетне скорочення $\mathrm{BO} \Sigma$ приховує батька епоніма 217 р. до н. е. на ім'я Ми̃ Воблоріхоv з роду Боспорихів. Нещодавно В. Ф. Столбою 4 опубліковано монету з легендою ВО $П О Р$, яка належить, вірогідно, дідові цього Боспориха; монета є відомим типом «Деметра - орел на дельфіні» та датується кінцем третьої - початком останньої чверті IV ст. до н. е. Отже, датування монети $з$ диферентом BO $\Sigma$ отримало підтвердження не тільки «знизу» (Мṽ епонім 217 р. до н.е.), а й «зверху» (легенда ВО $Г О Р \mathrm{O}$, кінець третьої- початок останньої чверті IV ст. до н. е.). Розрахунковий пік активності Боспориха - 247 р. до н. е., приблизно відповідає датуванню диференту № 68 за порядком розташування $-239^{+12}$ р. до н. е.

Отже, внаслідок виявленої кореляиії деяких диферентів із патронімами епонімів 220-208 рр. до н. е., друга частина «борисфенів» групи $V$ за законом генеалогії має абсолютні дати в діапазоні 250-240 рр. до н.е.

Завершуючи розгляд четвертої-п'ятої групи, також фіксуємо використання спільного лицьового штемпеля 5 впродовж двох років; першій рік магістрат $\Lambda$. Згодом. упродовж наступного року, другий магістрат із двома варіантами диферентів NoY NO тобто $\Lambda$ E NoY NO. П'ята група також утримує кілька чотирирічних спільних штемпелів,

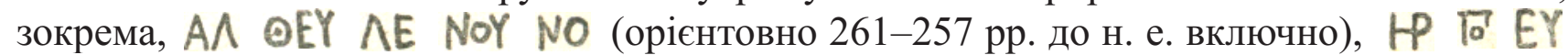
Вог (орієнтовно 242-239 pр. до н. е. включно) тощо.

Група VI (Karyshkovskij C. 81. № 69-78).

A.(Karyshkovskij C. 81. № 69). Ономастичній інтерпретації не піддається6'. Пропонуємо обережну гіпотезу про читання монограми рідкісним ім'ям 'Аүро́таৎ, що належить відомій історичній особі - Агрота, сину Діонісія з роду Діонісіїв, дедиканта посвят IOlb 68, IOlb 70 та одного з дедикантів посвяти IPE I² 189 Аполлону свого батька Діонісія близько 230 р. до н. е. Ці посвяти знаменують новий етап кланової боротьби в Ольвії ${ }^{7}$, повернення (мабуть, 3 вигнання) до влади Діонісіїв, наругу над декретом Аристократидів SEG 34:758 на честь Антестерія, що їі виконав молодший брат Агрота,

${ }^{1}$ Николаев Н. И. Просопография Ольвии... С. 200.

2 Ніколаєв М. І. Просопографія та ономастика... С. 17.

3 Також див. монети «Деметра-голова Афіни» (Nechitailo № 402) з легендою EY.

${ }^{4}$ Столба В. Ф. Новые разновидности монет Херсонеса и Ольвии периода автономии // «ПриРОNТийский меняла: деньги местного рынка». VII Международный Нумизматический Симпозиум (Судак, 21-25.09. 2020 г.). Материалы научной конференции / отв. ред. Н. А. Алексеенко. Симферополь: Колорит, 2020. С. 208-209. Також див. наш коментар до статті: https://www.academia.edu/44049919.

5 Анохин В. А. «Борисфены» и их место... С. 3-35.

${ }^{6}$ Фролова Н. А., Абрамзон М. Г. Монеты Ольвии... С. 227.

Николаев Н. И. Борьба кланов в Ольвии.. 
Посидей ${ }^{1}$. Спрощений розрахунок піку активності Агрота - 230 р. до н. е., виконано через застосування патроніма сина Агрота, епоніма 200 р. до н. е., якогось Діонісія Агрота

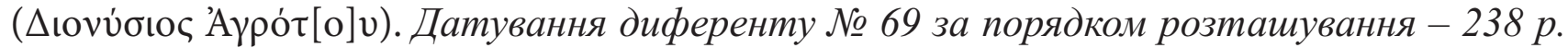
до н. е. приблизно відповідає спрощеному розрахунку піку активності Агрота - 230 р. до H. e.

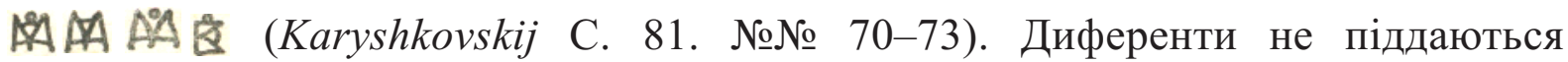
інтерпретації. Гіпотеза про родове наслідування диференту № 5 прийнятна 3 огляду на закон генеалогії${ }^{2}$. Датування диферентів №№ $70-73$ за порядком розташування - 237 р. до н. е.

4d (Karyshkovskij C. 81. № 74). Просопографічній інтерпретації не піддається. Датування диференту № 74 за порядком розташування - 236 р. до н. е.

Е 즐 (Karyshkovskij C. 81. № 75-77). Впадає в око cхожість диферентів №№ 75-77 з диферентами №№ 13 - 14 магістрата та епоніма 320 р. до н. е. на ім’я

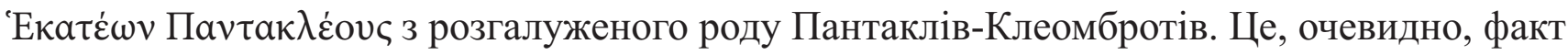

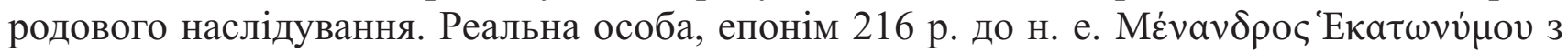
гілки роду Пантаклів-Клеомбротів має патронім, що відповідає диферентам №№ 75-77. Спрощений розрахунок піку активності батька цього Менандра - Гекатеоніма - «тяжіє» до 246 р. до н. е. Датування диферентів № 75-77 за порядком розташування - 235 р. до н. е.

IOM (Karyshkovskij C. 81. №78). Імена, що починаються на Іоц... відсутні. Інтерпретація скорочення IOM, на противагу думці П. О. Каришковського ${ }^{3}$, як варіант, може бути ретроградним відображенням диференту № 51 MOI. Втім, про ідентичність осіб IOM та MOI стверджувати не можливо. Датування диференту № 78 за порядком розташування - 234 р. до н. е.

Група VII (Karyshkovskij: 81. № 79-81). Починаючи із сьомої групи, наші дослідження будуть враховувати встановлену П. О. Каришковським 4 можливість перерви між групами VIII, IX, X та, за В. О. Анохіним ${ }^{5}$, існування перехідних штемпелів лицьової сторони для двох диферентів з однієї групи та відсутність перехідних штемпелів до сусідніх груп.

AH (Karyshkovskij C. 81. №7 9). 3 вірогідністю, наближеною до реального історичного факту, диферент є спрощенням родового наслідування скорочення $\Delta \mathrm{HMH}$

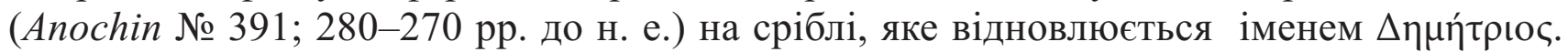
Відповідно, оцінне датування скорочення № $79-220$ рр. до н. е. 3 іншого боку, оскільки патроніми більшості епонімів 220-208 рр. до н. е. корелюють із диферентами «борисфенів», охоплюючи другу половину випусків n'ятої групи, переходячи за стовпцем епонімного каталогу нижче, маємо можливість знайти згадку про иьього Деметрія $в$ епонімному каталозі у вигляді його патроніму. Дійсно, виявляємо епоніма 197 р. до н. е.

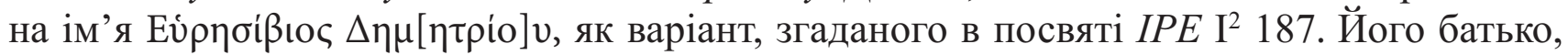

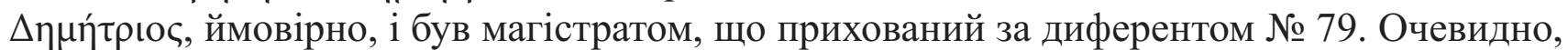
бувши молодим, цей Деметрій обіймав посаду третього агоранома за головного агоранома Протогена 6 . Орієнтовний розрахунок піку активності Деметрія - 227 р. до н. е.

Al A (Karyshkovskij $\quad$ C. 81. №№ 80, 81). Диференти не піддаються просопографічній інтерпретації. Втім, нам відомий новий графічний варіант диференту № 81 (не опублікований); у ньому досить виразно читаються літери API, що гіпотетично

\footnotetext{
Молодший брат Посидей не ідентифікується з магістратом, що залишив диферент № 66; відомо, що в ранньому другому столітті до н. е. він мав уже досить поважний вік (декрет $I G 813$ ).

2 Одне $з$ формулювань закону генеалогії: на сто років припадає діяльність трьох поколінь.

${ }^{3}$ Карышковский П. О. Монетное дело... С. 136.

${ }^{4}$ Карышковский П. О. Ольвийские «борисфены»... С. 72.

${ }^{5}$ Анохин В. А. «Борисфены» и их место... С. 17-19.

${ }^{6}$ Див. лему до диференту № 52.
} 


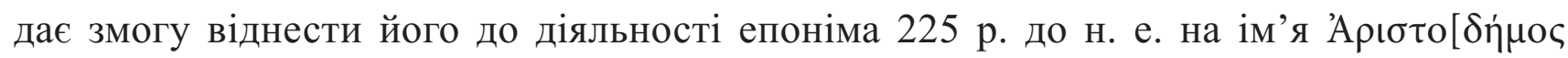
$\Delta$ aїкрátov?]. Батько цього Аристодима відомий участю в колегії агораномів разом із Протогеном ${ }^{1}$. Втім, ризик просопографічної інтерпретації високий. Орієнтовне датування групи VII з диферентами №№ 79, 80, $81-232-231$ рр. до н. е.

Групи VIII, IX, X (Karyshkovskij C. 81. № 82-93)². Різке, майже у шість разів, зростання об'єму емісії, можливо, призвело до відмінних від попередніх організаційних або технологічних умов карбування. Тож пропонуємо лише попередні, робочі гіпотези.

А

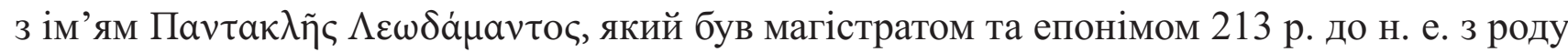
Пантаклів-Клеомбротів ${ }^{3}$. Диференти №№ 82, 83 мають спільні графічні риси 3 диферентом $\mathbb{R}$ (№ 57; близько 248 р. до н. е.), який також належить реальній історичній особі з розгалуженого роду Пантаклів-Клеомбротів - батькові епонімів 222 та 211 рр. до н. е.

MHMHMIM (Karyshkovskij C. 81. №o 84, 85). 3 урахуванням нових диферентів M та MI, на відміну від раніше пропонованої нами гіпотези ${ }^{4}$ інтерпретація диферентів №o 84, 85 ускладнюється. Втім, із застосуванням принципу тлумачення монограм, що подібний до №№ 86, 87, 89, можлива гіпотеза про інтерпретацію послідовно спрощуваних монограм як таких, що належать особі, ім'я якої починалося на M, а патронім - на I,

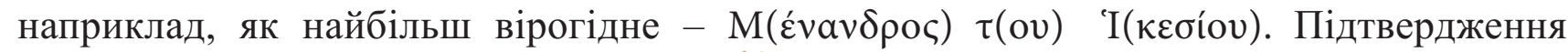
патроніму цього магістрата - скорочення $\mid K$ приблизно 255 р. до н. е. Диференти №№ 84, 85 мають деякі спільні риси $з$ диферентами $\mathrm{M}$ MH (№o 59, 54). Можливо, у даному випадку ми також, як і в диферентах №o 82, 83, стикаємося зі співпадаючими іменами розгалуженого роду Пантаклів-Клеомбротів із суміжного покоління. Орієнтовне датування групи VIII (диференти №№ 82, 83, 84, 85) - 228-227 р. до н. е.

MP MB M (Karyshkovskij C. 81. №№ 86, 87, 89). В. О. Анохін що ці три монограми стосуються однієї особи та ілюструють послідовне спрощення. Просопографічна інтерпретація монограм обгрунтована нами раніше та має статус,

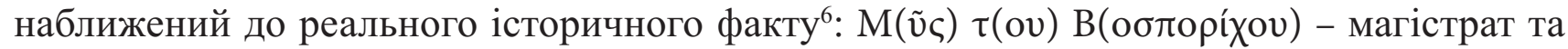
епонім 217 р. до н. е. Майже тридцять років тому батько цього Мica, якийсь Вобторіхо

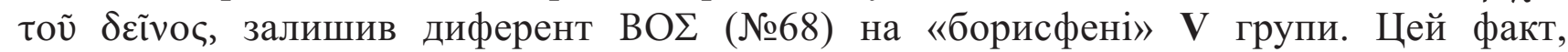
підтверджуючи спадкоємність обіймання посади магістратів у роду Боспорихів, - також аргумент на користь ідентифікації монограм №№ 86, 87, 89.

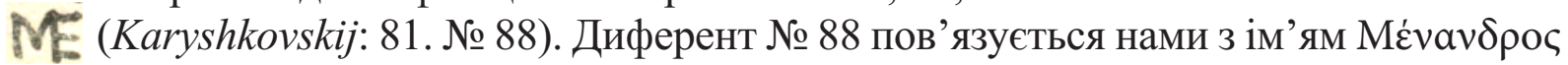

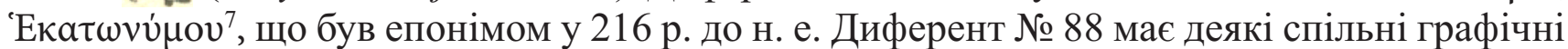
риси з диферентом ME (№58). Можливо, у даному випадку ми також, як і в диферентах №o 82, 83, стикаємося зі співпадаючими іменами із суміжного покоління розгалуженого роду Пантаклів-Клеомбротів. Група IX, до якої входять диференти №№ 86, 87, 88, 89, орієнтовно датується 225-224 рр. до н. е.

¿̌M (Karyshkovskij C. 81. № 90). Як варіант, згідно з традицією наслідування монограм можлива гіпотеза про спорідненість цього магістрата 3 магістратом, що

\footnotetext{
Див. лему до диференту № 43.

2 Перш ніж переходити до дослідження VIII, IX, X груп, нагадаємо читачеві про встановлений нами раніше зв'язок срібних монет 220-190 рр.

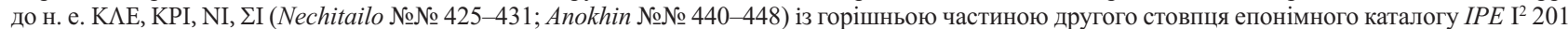
та деяких лапідарних написів, агораномних клейм та гир (див.: Николаев Н. И. Просопография Ольвии... С. 218-219). Зокрема, скорочення

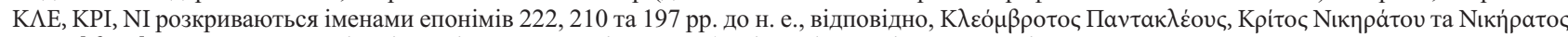
Ev́p $\sigma[ı$ iov], із впливових родів Нікератів та Пантаклів-Клеомбротів. Інформація ж про магістрата $\Sigma$ I присутня у майже синхронному агораномному клеймі, але, на жаль, не піддається просопографічній інтерпретації (див.: Николаев Н. И. Агораномы эллинистической Ольвии... C. 405).

${ }^{3}$ Николаев Н. И. Просопография Ольвии... С. 218-219.

${ }^{4}$ Там само ... С. 220. Існування диференту з літерою Р не підтвердилося.

5 Анохин В. А. «Борисфены» и их место... С. 19.

${ }^{6}$ Николаев Н. И. Просопография Ольвии... С. 219

Там само. С. 218-219.
} 
залишив диферент на «борисфені» № 27 та синхронне йому скорочення $\Sigma \Upsilon$ М на срібній монеті (Anokhin № 398) № 90, як діда з онуком. Відповідно, датування «борисфена» із диферентом № 90 орієнтовно «тяжіє» до 220-210 рр. до н. е. Магістрат не обіймав посаду епоніма.

API AP (Karyshkovskij C. 81. №o 91, 92). Для хронологічного періоду, що розглядається в історії Ольвії, характерне домінування Нікератів та ПантаклівКлеомбротів ${ }^{1}$. Скорочення, найімовірніше, ілюструють обіймання посади монетного

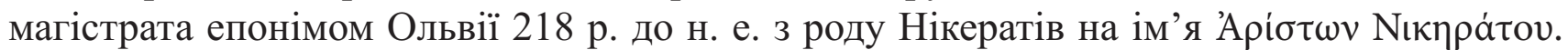
Цей Аристон також обіймав посаду голови колегії агораномів, про що свідчить

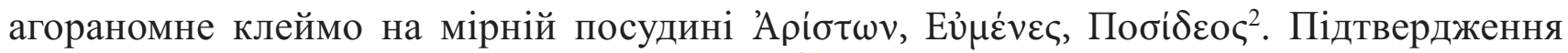
патроніма цього магістрата - скорочення $\mathbb{N}$ | близько 245 р. до н. е. Зі скороченнями №№ 91, 92 хронологічно пов’ язані скорочення №№ 33, 34, підтверджуючи традицію наслідування.

Скорочення № 92 утримує яскраву палеографічну особливість: уперше в Ольвії застосована альфа з ламаною поперечною гастою. В ольвійській лапідарній палеографії така альфа відома 3 кінця III ст. до н.е. Отже, за палеографією датування «борисфенів» зі скороченням № 92 не може бути ранішим останньої третини III cm. до н. е.

Eㅣ (Karyshkovskij C. 81. № 93). Прикінцевий випуск «борисфенів» згідно 3 нашою робочою гіпотезою також знаходить просопографічний зв'язок з одним із братів

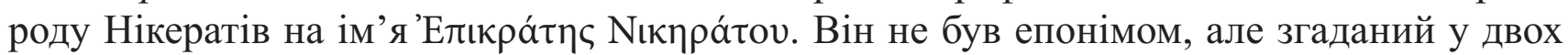
монументальних посвятах IPE I² 190 та IPE I² 191, котрі датуються 217-198 pр. до н.е ${ }^{4}$.

Орієнтовні датування прикінцевих випусків «борисфенів» із диферентами №№ 90, 91, 92, 93 - 222-219 рр. до н. е. Сподіваємося на появу нумізматичних досліджень останніх груп «борисфенів», зокрема, аналіз спільних штемпелів лицьової сторони, щэо дасть змогу уточнити запропоновані хронологічні гіпотези.

Висновки. 1. Із застосуванням синхронізованого епонімного каталогу та основ просопографії Ольвії пропонується гіпотеза про початок емісії «борисфенів» 330 р. до н. е., завершення - орієнтовно 219 р. до н. е. Тобто, разом із перервами емісія продовжувалася майже 110 років. Перша група «борисфенів» датується з 330 до 319 рр. до н. е. включно, друга - з 307 до 301 рр. до н. е. включно, третя - у діапазоні $290-271^{+12}$ pp. до н. е., четверта-шоста (37 рокових випусків) - орієнтовно з $270^{+12}$ до $234^{+12} \mathrm{pp}$. до н. е. включно 5 . Звертаємо увагу, щзо патроніми великої групи епонімів 220-208 рр. до н. е. корелюють із диферентами «борисфенів» другої половини випусків $\boldsymbol{V}$ групи, підтверджуючи, згідно з законом генеалогії, їхнє датування в діапазоні 250-240 рр. до н. $e^{6}$. Отримане нами просопографічне датування груп «борисфенів» із першої до шостої включно суттєво протирічить схемі В. О. Анохіна та однозначно дозволяє подолати альтернативу на користь схеми П. О. Каришковського (з необхідністю подальшого уточнення датувань окремих груп «борисфенів»). Також, отримані орієнтовні датування сьомої-десятої груп у діапазоні $232^{+12}-219$ рр. до н. е.

2. У диференті № 92 вперше в Ольвії застосована альфа з ламаною гастою, тобто, за палеографією датування «борисфенів» з диферентом № 92 прикіниевої групи не може бути раніше останньої третини III cm. до н. е.

\footnotetext{
Николаев Н. И. Просопография Ольвии... С. 219.

${ }^{2}$ Николаев Н. И. Агораномы эллинистической Ольвии... С. 404

${ }^{3}$ Николаев Н. И. Просопография Ольвии... С. 305-306.

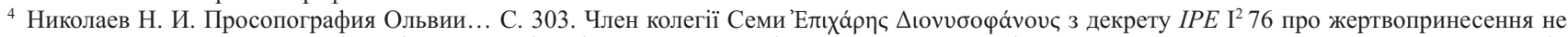
створює альтернативного варіанту інтерпретації диференту № 93, оскільки належить до невідомого другорядного роду, участь якого в монетній справі не доведена. До того ж, згідно із сучасним алгоритмом датування декрету IPE I² 76 ( 3 урахуванням віку голови колегії), дата цього декрету «тяжіє» до останніх років III ст. до н. е. Див.: Николаев Н. И. Развитие просопографической модели... С. 99-104.

5 Побудована нами хронологічна модель для четвертої-шостої груп - оцінна та потребує подальшого вдосконалення; зокрема, теоретично датування можуть бути заниженими не більше ніж на 12 років.

' Саме ця кореляція, зокрема, становить основу для подальшої хронологічної оптимізації нашої хронологічної моделі.
} 
3. Нікерати та Пантакли-Клеомброти близько 220 р. до н. е., завершивши випуск «борисфенів», розпочали реалізацію грошово-економічної реформи, зокрема з ліквідації боргів (декрет IOlb 28+29+123+IPE I² 240 на честь синів херсонесита Аполлонія 215 р. до н. е.) та емісії срібла К $\Lambda$, KPI, NI, яка добре датується та ідентифікується з відомими історичними особами. У цей час, вважаємо, «борисфени» отримали клейма «дельфінзірка» ${ }^{1}$.

4. П. О. Каришковський ${ }^{2}$ залишав відкритим питання про приналежність диферентів міським епонімам або магістратам. В. О. Анохін ${ }^{3}$ відхиляв гіпотезу про епонімний характер диферентів. Нами, завдяки синхронізації епонімного каталогу Ольвії $I P E \mathrm{I}^{2}$ 201, встановлено реальний історичний факт: диференти на «борисфенах» не мають епонімного характеру, однак деяка частина з них, орієнтовно 50-60\%, позначає осіб-монетних магістратів ${ }^{4}$, які згідно з античною традицією в суміжні роки обіймали епонімну посаду (зазначене співвідношення притаманне й іншим магістратурам, зокрема, агораномів) $)^{5}$. До речі, аналогічний приниип використовувався $і$ в скороченнях монет з Деметрою 360-330 рр. до н. е. Це відкриває перспективу виконання датувань диферентів.

5. Диференти (монограми, скорочення), як і родові імена, підпорядковані стійкій в античному суспільстві традииї родового наслідування. Зазвичай, у разі застосування особами з наступних поколінь, пов'язаних родинними узами, диференти зазнавали спрощення (наприклад, $\Sigma \Omega \mathrm{KP} \rightarrow \Sigma \Omega \mathrm{K} \rightarrow \Sigma \Omega$ та $\Theta \mathrm{EO} \rightarrow \Theta \mathrm{E}$ або $\mathrm{A \Theta H} \rightarrow \mathrm{A \Theta}$, або Е $\mathrm{BIO} \rightarrow \mathrm{E} \Upsilon \mathrm{B}$, або $\mathrm{BO} \Sigma \Pi \mathrm{OPI} \rightarrow \mathrm{BO} \Sigma$ тощз), проте, цуе лише тенденція. Саме тому припущення В. О. Анохіна 6 про належність диферентів, щзо повторюються, до однієї особи, яка неодноразово брала участь у карбуванні, та, відповідно, про тривалість випуску «борисфенів» не більще двох-трьох десятиліть повинно бути відхилено; цче припущення суперечить стійкій античній традииї наслідування.

6. Висновки В. О. Анохіна ${ }^{7}$ про обмежену кількість різьбярів (один чи два), які виготовляли штемпелі для будь-якої групи «борисфенів», відповідає фактичній тривалості емісії такої групи, тобто, щорічному супроводу емісії одним-двома різьбярами (наприклад, першої - з 330 до 319 рр. до н. е., чи другої - 3307 до 301 рр. до н. е. тощо) з відповідними наслідками щодо збереження лицьових штемпелів.

7. Під час вивчення скарбу 1978 р. В. О. Анохіним встановлений масовий характер зв'язку двох і більше диферентів за рахунок спільних лицьових штемпелів, звідси головним висновком дослідника стало припущзення про існування спеціальних колегій магістратів, які для I-VI групи налічували шість осіб, а для останніх груп - дві особи відповідно, тривалість випуску «борисфенів» складала не більше двох-трьох десятиліть. Головна гіпотеза В. О. Анохіна грунтується на вагомому протиріччі між об'ємами емісій, кількістю магістратів та кількістю спільних лицьових штемпелів для перших та останніх груп. Так, за моделлю дослідника, об 'єми емісії останніх груп, які зросли майже у шість разів стосовно перших, супроводжувалися зменшенням кількості магістратів із шести до двох, та, відповідно, зменшенням кількості спільних штемпелів, зокрема, з трьох-чотирьох до двох, щзо абсолютно нелогічно. Критичні зауваження до схеми

\footnotetext{
Ми не прихильники гіпотез, які базуються на унікальних монетах, проте не можливо проігнорувати інформацію П О. Карищковського про «борисфен» із випадковим клеймом «Геліос-протоми коней», на якому згодом був накладений шттамп «дельфін-зірка». Див.: Карышковский П. О. Ольвийские «борисфены»... С. 78.

2 Карышковский П. О. Ольвийские «борисфены»... С. 71

3 Анохин В. А. «Борисфены» и их место... С. 23

4 У цій статті ми не даємо вичерпного визначення терміна «монетний магістрат». Орієнтовно це особа, яка організаційно або фінансово пов'язана 3 випуском тієї чи іншої серії монет.

Див.: Николаев Н. И. Агораномы эллинистической Ольвии... С. 392-406.

6 Анохин В.А. «Борисфены» и их место... С. 25-26.

Там само, С. 23

${ }^{8}$ Там само, С. 23.
} 
В. О. Анохіна були сформульовані П. О. Каришковським ${ }^{1}$. Проте, схема В. О. Анохіна набула деякого поширення ${ }^{2}$. У світлі отриманих просопографічних даних нами виконано подальший критичний аналіз схеми В. О. Анохіна. Зокрема, встановлений зв'язок 50-60\% магістратів з епонімним каталогом спростовує гіпотезу дослідника про однорічну емісію за участю шістьох магістратів для першоӥ-шостої групи. Що стосується останніх груп, за умови різкого збільшення об 'єму емісій, не виключена, як варіант, за гіпотезою В. О. Анохіна, участь двох магістратів ${ }^{3}$; але на сучасному етапі дослідження така гіпотеза не може бути ані підтверджена, ані спростована 4 . Ми є прибічниками традиційної організації монетної справи за участю одного магістрата.

Надамо пояснення факту наявності спільних лицьових штемпелів для перших шести груп. Отже, застосування спільних штемпелів упродовж кількох років (не більше чотирьох) не становить однорічну емісію групи магістратів, а представляє реалізацію відомої в античній монетній справі технології, яка передбачала використання кількох однотипних лицьових штемпелів, розташованих поряд на ковадлі. Поява такої технології иілком зрозуміла з огляду на тривалість та інтенсивність випуску6. Нам невідомі принципи, якими керувалися монетарії у разі використання того чи іншого лицьового штемпеля, але, вірогідно, така технологія забезпечувала умовно рівномірне їх зношення; своїм наслідком вона мала появу монет із різними комбінаціями диферентів, пов'язаними спільними лищьовими штемпелями, упродовж декількох років. Зауважимо, щзо В. О. Анохін в іншій праці надає приклад існування спільних лищьових штемпелів для монет Тіри упродовж п'ятив-восьми років

8. В. О. Анохін ${ }^{8}$ вважав, що разом 3 останніми групами «борисфенів» в обігу перебували срібні монети «Деметра-дельфін» (див.: Anokhin №№ 387-401; 280-270 pp. до н. е.). Відповідно, саме ці монети повинні були знаходитися у скарбі 1978 р. Наявність же в ньому двох статерів ${ }^{9}$ останньої чверті IV cm. до н. е. свідчить про те, щзо, ймовірно, вони потрапили до скарбу, (якій ми датуємо орієнтовно 220 рр. до н. е.), до иъього часу перебуваючи в обігу (Karyshkovskij C. 88 сн. 22).

9. Ономастичним дослідженням притаманна багатоваріантність тлумачення диферентів без наявності історичного контексту. Але, й наше просопографічне дослідження стикається як з повною неможливістю інтерпретації, так $і$ з наявністю двох, іноді і трьох варіантів тлумачення, але, на відміну від ономастики, изі варіанти мають історичний складник. Завдання полягає лише в переборенні альтернативного варіанту, що також не завжди можливо здійснити.

10. Просопографічне дослідження диферентів на «борисфенах» усіх груп виконано вперше, тому його треба сприймати як оцінне та наближене. 3 огляду на складність завдання, очевидна необхідність подальших досліджень 3 метою подолання альтернативних варіантів інтерпретації, уточнення та отримання нових аргументів (зокрема, спільним розглядом з агораномними клеймами) щодо запропонованих гіпотез. Необхідна й ревізія інтерпретації скарбів «борисфенів», розгляд нових варіантів

\footnotetext{
Karyshkovskij С. 82 (також із посиланням на статтю В. М. Урсалова). Ми приєднуємося до зауважень П. О. Каришковського.

Вважаємо, що поширення хронологічної схеми В. О. Анохіна, насамперед, сталося через передчасну смерть П.О. Каришковського.

3 В. О. Анохін надає ще один аргумент - спостереження за ступенем зносу двох лицьових штемпелів VIII групи (див.: Анохин В. А. «Борисфены» и их место... С. 16-18). На нашу думку, це явище зафіксоване одноразово та може бути наслідком суб'єктивного бачення або ступеня збереженості монети чи випадковим збігом обставин, наприклад, завершенням об'єму емісії одного відкупника за умови вже розпочатої емісії другого тощо. Втім, не виключений і варіант двох магістратів (див. п.7 Висновків).

4 Вибірка (скарб 1978 р.), яку дослідив В. О. Анохін, не репрезентативна з огляду на об 'єм емісії останніх груп. Необхідне залучення нових матеріалів про спільні лицьові штемпелі.

5 Зограф А. Н. Античные монеты... С. 31; Карышковский П. О. Монетное дело... С. 34-35.

6 Згідно з матеріалами (див.: Анохин В. А. «Борисфены» и их место... рис. 14), максимальний строк існування спільного лицьового штемпеля склав чотири роки лише у двох-трьох випадках, відповідно, емісія цих проміжних груп «борисфенів» порівняно 3 останніми групами була порівняно невеликою.

Анохин В. А. Монеты... С. 91

${ }^{8}$ Анохин В. А. Монеты... С. 41.

9 Анохин В. А. «Борисфены» и их место... С. 23.
} 
диферентів на «борисфенах», співвідношення «борисфенів» 3 іншими монетами, родове наслідування диферентів а також порівняння результатів нумізматичних досліджень із просопографічними, зокрема аналіз вагомості аргументів дослідників, які пропонують альтернативні варіанти хронології «борисфенів», тощо. Осібним напрямком подальших розвідок виступає удосконалення запропонованої очінної хронологічної моделі карбування «борисфенів», оскільки ия модель містить недоліки у датуванні груп III, IV-VI, VII-X, розташованих у хронологічній лакуні каталогу IPE $\mathrm{I}^{2} 201$.

\begin{tabular}{|c|c|c|c|c|c|c|}
\hline \multicolumn{7}{|c|}{ ХРОНОЛОГІЯ ОЛЬВІЙСЬКИХ «БОРИСФЕНІВ» } \\
\hline \multicolumn{7}{|c|}{ Група I. 330-319 рр. до н. е. } \\
\hline $\begin{array}{l}\text { № } 1,2 \\
330\end{array}$ & \begin{tabular}{|l|} 
№ 3 \\
329
\end{tabular} & \begin{tabular}{|l|}
$№ 4$ \\
328
\end{tabular} & $\begin{array}{l}\text { № } 5 \\
\text { 327 }\end{array}$ & $\begin{array}{l}\text { № } 6 \\
326\end{array}$ & $\begin{array}{l}\text { № 7,8 } \\
325\end{array}$ & \begin{tabular}{|l|} 
o. 9 \\
324
\end{tabular} \\
\hline EEE & $\phi$ & $\Gamma$ & 降 $\mathrm{AA}$ & Q B & $\notin \oplus$ & IE \\
\hline $\begin{array}{l}6 / H \\
323\end{array}$ & \begin{tabular}{|l|} 
№ 10 \\
322
\end{tabular} & \begin{tabular}{|l|} 
№ 11 \\
321
\end{tabular} & \begin{tabular}{|l|} 
№ 12 \\
320
\end{tabular} & $\begin{array}{l}\text { № 13, 14 } \\
\mathbf{3 1 9}\end{array}$ & & \\
\hline$\varepsilon$ & 王 & $A$ & $\Delta$ & $\exists \quad \exists$ & & \\
\hline \multicolumn{7}{|c|}{ Група II. 307-301 рр. до н. е. } \\
\hline № 15 & № 16 & 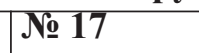 & № 18 & № 19 & № 20 & |№ 21 \\
\hline & & & & 303 & & 301 \\
\hline 过 & $N$ & N & $\mathrm{X}$ & $A P$ & IK & $\phi \mid$ \\
\hline \multicolumn{7}{|c|}{ Група III. Не раніше 290 р. до н. е., не пізніше $271^{+12}$ р. до н. е. } \\
\hline № 22 & № 23 & № 24 & № 25 & № 26 & № 27 & \\
\hline A & $\Sigma \Omega$ & 170 & $E$ & M & $\Sigma Y$ & \\
\hline \multicolumn{7}{|c|}{ Групи IV, V, VI. $270^{+12}-234^{+12}$ рр. до н. е. } \\
\hline № 28, 29 & № 30 & № 31, 32 & № 33, $\mathbf{3 4}$ & № 35 & № 36 & № 37 \\
\hline $270^{+12}$ & $269^{+12}$ & $268^{+12}$ & $267^{+12}$ & $266^{+12}$ & $265^{+12}$ & $264^{+12}$ \\
\hline I I & NA & A $A$ & API AP AP & EK & $\Delta 1$ & $O E$ \\
\hline № 38 & №39,40, 41 & № 42 & \begin{tabular}{|l|l|} 
№ 43 \\
\end{tabular} & № 44 & № 45 & № 46, 47 \\
\hline $263^{+12}$ & $262^{+12}$ & $261^{+12}$ & $260^{+12}$ & $259^{+12}$ & $258^{+12}$ & $257^{+12}$ \\
\hline Hr H & $\Gamma \pi \mathbb{A}$ & $\Delta l$ & $\mathrm{~A} \Lambda$ & OEY & $\Lambda E$ & NoY NO \\
\hline № 48 & № 49 & № 50 & № 51 & № 52 & № 53 & № 54 \\
\hline $256^{+12}$ & $255^{+12}$ & $254^{+12}$ & $253^{+12}$ & $252^{+12}$ & $251^{+12}$ & $250^{+12}$ \\
\hline AR & IK & AP & Mol Mo & $\phi \Omega$ & $E$ & $M$ \\
\hline № 55,56 & № 57 & № 58 & № 59 & № 60 & |№ 61 & № $62,63,64$ \\
\hline $249^{+12}$ & $248^{+12}$ & $247^{+12}$ & $246^{+12}$ & $245^{+12}$ & $244^{+12}$ & $243^{+12}$ \\
\hline 主姜 & $\sqrt{A}$ & $M E$ & $\mathrm{MH}$ & N & AO & W U W \\
\hline № 65 & № 66 & № 67 & № 68 & № 69 & № 70-73 & № 74 \\
\hline $242^{+12}$ & $241^{+12}$ & $240^{+12}$ & $239^{+12}$ & $238^{+12}$ & $237^{+12}$ & $236^{+12}$ \\
\hline$H P$ & $T 0$ & $E Y$ & BOE & A & $\triangle A A A B$ & $4 d$ \\
\hline $\begin{array}{l}\text { № } 75-77 \\
2^{235^{+12}}\end{array}$ & \begin{tabular}{|l|}
$№ 78$ \\
$234^{+12}$
\end{tabular} & & & & & \\
\hline 国汇 & $10 \mathrm{M}$ & & & & & \\
\hline \multicolumn{7}{|c|}{ Групи VII, VIII, XI, X. $232^{+12}-219$ рр. до н. е. (оріснтовні дати) } \\
\hline № 79 & № 80-81 & № 82-83 & № б/H, 84-85 & № 86,87,89 & № 88 & б/H \\
\hline 232 & 231 & 228 & 227 & 225 & 224 & \\
\hline$\Delta H$ & $\mathbb{A} \mathbb{A}$ & 压闪 & MHMMIM & MAMB MB & $M$ & M \\
\hline №90 & № 91-92 & № 93 & & & & \\
\hline$\sum Y M$ & API AP & ${ }_{\text {ENI }}^{219}$ & & & & \\
\hline & & & & & & \\
\hline
\end{tabular}

Табл. 1. Хронологія ольвійських «борисфенів». Номери диферентів на «борисфенах» відповідають таблиці (Karyshkovskij C. 82). Додано орієнтовні абсолютні дати, згідно з пропонованою хронологічною моделлю 


\section{REFERENCES}

Anohin, V. A. (1984). «Borisfeny» i ih mesto v monetnoj sisteme Ol'vii. ["Borisphens" and their place in the monetary system of Olbia]. Antichnaja kul' tura Severnogo Prichernomor'ja. [Ancient culture of the Northern Black Sea region]. Kyiv. S. 3-36. [In Russian].

Anohin, V. A. (1989). Monety antichnih gorodov Severo-Zapadnogo Prichernomor'ja. [Coins of ancient cities of the North-Western Black Sea region]. Kyiv. [In Russian].

Belousov, A., Dana, M., Nikolaev, N. (2016). Deux nouvelles defixionum tabellae du territoire d'Olbia du Pont. Zeitschrift für Papyrologie und Epigraphik. Bd. 197. S. 167-177. [In French].

Karyshkovskij P. Y. (1959). Olviiski monety, znaideni poblyzu Odesy. [Olvian coins found near Odessa]. Pratsi ODU. Odesa. Vyp. 7. P. 138-142. [In Ukrainian].

Karyshkovskij, P. O. (1968) Ol'vijskie borisfeny [The Olbian Borysphens]. Numizmatika i sfragistika [Numismatics and Sphragistics], 3, 62-85 [In Russian].

Karyshkovskij, P. O. (1978) Ol'vijskie jeponimy. [The Olbian eponyms].Vestnik drevnej istorii [Journal of ancient history], 2, 82-88 [In Russian].

Karyshkovskij, P. O. (2003). Monetnoe delo i denezhnoe obrashhenie Ol'vii [Coins of Monetary Circulation in Olbia] Odessa: Friedman A. S. [In Russian].

Knipovich, T. N. (1956). Naselenie Ol'vii v VI - I vv. do n.je. [Sitizens of Olbia in VI-I cent. BC] Ol'vija i Nizhnee Pobuzh'e v antichnuju jepohu. Ed. V. F. Gajdukevich. Moscow; Leningrad. [In Russian].

Mielczarek, M \& Orlyk, V. (2019). New find of Olbian coins. Tarashcha district, Kyiv region, Ukraine. Skhidnoievropeiskyi Istorychnyi Visnyk [East European Historical Bulletin], № 13, P. 33-39 [In English].

Nikolaev, N. I. (2014). Prosopografija Ol'vii Pontijskoj V v. do n. je. $-I$ v. n. je. [Prosopography of Olbia Pontika V cent. B.C. - I cent. A. D.]. Kyiv: [In Russian].

Nikolaev, N. I. (2017). Ol'vijskie dekrety v chest' grazhdan Hersonesa v kontekste lokal'nyh hronologij Ol'vii, Hersonesa i Pontijskogo carstva. [Olbian decrees in honor of citizens of Chersonesos in context of local chronologies of Olbia, Chersonesos and Pontos]. Aristej, XV, 55-76 [In Russian].

Nikolaev, N. I. (2018). Bor 'ba klanov v Ol'vii IV-III vv. do n. je. [The Struggle of the Clans in Olbia of the 4th - 3rd Centuries BC]. Stratum Plus, 6, 73-87. [In Russian].

Nikolaev, N. I. (2018). Agoranomy jellinisticheskoj Ol'vii. [Agoranomos of the Hellenistic Olbia]. Prichernomor'e v antichnoe i rannesrednevekovoe vremja. Vyp. 2. Sbornik nauchnyh trudov, posvjashhennyj 70-letiju profesora V. P. Kopylova. Rostov-na-Donu. S. 392406. [In Russian].

Nikolaev, N. I. (2018). Razvitie prosopograficheskoj modeli obshhiny nebol'shogo antichnogo goroda (na primere Ol'vii) [Development of a Prosopographical Model of a Small Ancient City Commynity (on the Example of Olbia]. Drevnie civilizacii: socium i chelovek [Ancient civilizations: society and man]. Jaroslavl. S. 99-104 [In Russian].

Nikolaev, N. I. (2019). O preobrazovanii onomasticheskogo materiala v polnocennyj istoricheskij istochnik (na primere novogo magicheskogo opistografa iz Ol'vii) [On the transformation of onomastic material into a full-fledged historical source (on the example of a new magical opistograph from Olbia)]. SCRIPTA ANTIQUA. S. 276-308. [In Russian].

Nikolaev, N. I. (2019). Prosopograficheskaja rekonstrukcija sokrashhennyh $i$ fragmentirovanny imen istoricheskih lic (na primere Ol'vii) [Prosopographical Reconstruction of the Reduced and Fragmented Names of Historical Persons (on the Example of Olbia)]. Eminak: nauk. shhokvartal'nik. № 1 (25). S. 149-157. [In Russian]. 
Nikolaev, M. I. (2019). Onomastyka ta prosopohrafiia u vidnovlenni monetnykh monohram (na prykladi Olvii IV st. do n. e.). [Onomastics and prospography in restoration of coin monograms (on the example of Olbia IV century B.C.)]. Ukrainskyi numizmatychnyi shchorichnyk. [The Ukrainian Numismatic Annual]. Issue 3. S. 5-27. [In Ukrainian].

Nikolaev, M. I. (2020). Olviia i Zopirion: nove istorychne dzherelo. [Olbia \& Zopyrion. A new Historical Source]. Tezy Mizhnarodnoho fakhovoho seminaru 'Problemy i perspektyvy antychnoi numizmatyky na terenakh Pivdenno-Skhidoi Yevropy'. In print. [In Ukrainian].

Orlyk, V. \& Kocur, V. \& Cyganenko, L. (2020). Klad ol'vijskih monet «borisfenov» najdennyj $v$ Gorodishhenskom rajone Cherkasskoj oblasti vesnoj 2018 goda. [A treasure of Olivian coins "borisphenes" found in the Gorodishchensky district of Cherkasy region in the spring of 2018]. Acta Archaeologica Lodziensia nr 65. S. 37-48. [In Russian].

Orlyk, V. (2020). Do pytannia isnuvannia hroshovoho obihu na terytorii Dniprovskoho Pravoberezhnoho lisostepu ( $V-I$ st. do n. e.). [ On the question of the existence of money circulation on the territory of the Dnieper Right-Bank Forest-Steppe (V-I centuries BC). Istoriia, arkheolohiia, informatsiina, bibliotechna ta arkhivna sprava: aktualni problemy nauky ta osvity: tezy dopovidei I Mizhnarodnoi naukovoi konferentsii, 13 travnia 2020 r. Kropyvnytskyi [History, archeology, information, library and archival business: current issues of science and education: abstracts of the I International Scientific Conference, May 13, 2020. Kropyvnytskyi, 2020. 184 p.] 184 S. [In Ukrainian].

Ruban, V. V. (1982). Mahistratura ahoranomiv v Ol'vii [Magistrature of agoranomos of Olbia]. Arkheolohiia [Archeology], 39. S. 30-40 [In Ukrainian].

Stavniuk, V. V. (2005). Stanovlennia afinskoho polisa [Formation of the Athenian polis]. Kyiv. 306 S. [In Ukrainian].

Stolba, V. F. (2005). Monetary Crises in the Early Hellenistic Poleis of Olbia, Chersonesos and Pantikapaion. A Re-assessment, in: C. ALFARO, C. MARCOS \& P. OTERO (eds.), XIII Congreso Internacional de Numismática (Madrid, 2003). Actas - Proceedings Actes. Madrid. 395-403.

Stolba, V. F. (2015). 'Archers' of the Blessed City: City’s Deliverance in the Coinage of Early Hellenistic Olbia. Notae Numizmaticae. Vol. 10. P. 43- 63 [In English].

Stolba, V. F. (2019). Images with Meaning: Early Hellenistic Coin Typology of Olbia Pontike. Advances in Ancient Black Sea Studies: Historiography, Archaeology and Religion. Editors: V. Cojocaru, L. Ruscu, T. Castelli and A-I. Pázsint. Cluj-Napoca. P. 523-541. [In English].

Stolba V. F. (2020). Novye raznovidnosti monet Hersonesa i Ol'vii perioda avtonomii. «PriPONTijskij menjala: den'gi mestnogo rynka». VII Mezhdunarodnyj Numizmaticheskij Simpozium. Materialy nauchnoj konferencii / otv. red. N. A. Alekseenko. Simferopol': S. 203211. [In Russian].

Turovskij, E. Ja. (2015). Aktual'nye voprosy numizmatiki Ol'vii (IV-III vv. do n.je.).[Actual issues of the numismatics of Olbia (IV - III centuries BC).]. Problemy istorii, filologii, kul'tury. [Problems of history, philology, culture]. №1. S. 421- 430. [In Russian].

Zograf, A. N. (1951). Antichnye monety [Antique coins]. Moscow. [In Russian].

Frolova N. A. \& Abramzon, M. G. (2005). Monety Ol'vii v sobranii Gosudarstvennogo istoricheskogo muzeja: katalog. [Coins of Olbia in the collection of the State Historical Museum: catalogue]. Moscow. 360 s [In Russian].

\section{Скорочення}

Anokhin - Анохин В. А. Античные монеты Северного Причерноморья: каталог. Киев. 2011. 328 с. [Antique Coins of the Northern Black Sea Region: Catalog]. Anohin V. A. Antichnye monety Severnogo Prichernomor 'ja: katalog. Kiev. 2011. 328 s. [In Russian]. 
IGDOlb - Dubois L. Inscriptions grecques dialectales d'Olbia du Pont. Genève. 1996. 208 p. [In French].

IOlb - Надписи Ольвии (1917-1965). Ленинград. 1968. - 133 с. [Inscriptions of Olbia]. Nadpisi Ol'vii (1917-1965). Leningrad. [In Russian].

IPE $\mathrm{I}^{2}-$ Latishev B. Inscriptiones antiquae orae septentrionalis Ponti Euxini Graecae et Latinae. Petropolis, 1885-1916. [In Latin].

Karyshkovskij - Карышковский П. О. Монеты Ольвии: очерк денежного обращения Северо-Западного Причерноморья в античную эпоху. Киев. [Coins of Olbia: a sketch of the monetary circulation of the North-Western Black Sea Coast in ancient times. Kiev.]. 1988. 166 c. Karyshkovskij P. O. Monety Ol'vii: ocherk denezhnogo obrashhenija Severo-Zapadnogo Prichernomor'ja v antichnuju jepohu. 1988. [In Russian].

Nechitailo - Нечитайло В. В. Каталог античных монет Ольвии. VI в. до н.э. III в. н.э. : каталог. Київ, 2000. 91 с. [Catalogue of antique coins of Olbia. VI century BC. III century AD ]. Nechitajlo V. V. Katalog antichnyh monet Ol'vii. VI v. do n.je. - III v. n.je. : katalog. Kï̈, 2000. [In Russian].

SEG - Supplementum Epigraphicum Graecum. Leiden, 1923-2003. [In English]. 